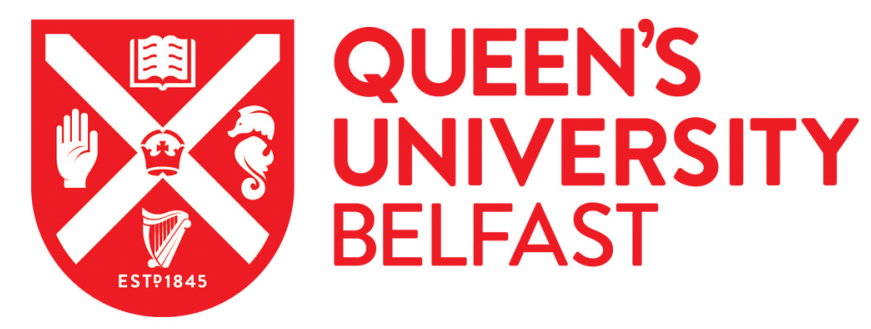

\title{
Linking Genes to Microbial Biogeochemical Cycling Lessons from Arsenic
}

Zhu, Y-G., Xue, X-M., Kappler, A., Rosen, B. P., \& Meharg, A. A. (2017). Linking Genes to Microbial Biogeochemical Cycling Lessons from Arsenic. Environmental science \& technology, 51(13), 7326-7339. https://doi.org/10.1021/acs.est.7b00689

\section{Published in:}

Environmental science \& technology

\section{Document Version:}

Peer reviewed version

Queen's University Belfast - Research Portal:

Link to publication record in Queen's University Belfast Research Portal

\section{Publisher rights}

Copyright $\odot 2017$ American Chemical Society. This work is made available online in accordance with the publisher's policies. Please refer to any applicable terms of use of the publisher.

\section{General rights}

Copyright for the publications made accessible via the Queen's University Belfast Research Portal is retained by the author(s) and / or other copyright owners and it is a condition of accessing these publications that users recognise and abide by the legal requirements associated with these rights.

Take down policy

The Research Portal is Queen's institutional repository that provides access to Queen's research output. Every effort has been made to ensure that content in the Research Portal does not infringe any person's rights, or applicable UK laws. If you discover content in the Research Portal that you believe breaches copyright or violates any law, please contact openaccess@qub.ac.uk. 
$1 \quad$ Linking genes to microbial biogeochemical cycling: lessons from arsenic

2 Yong-Guan Zhu, ${ }^{\dagger}$, $, \#, *$ Xi-Mei Xue, ${ }^{\dagger}, \#$ Andreas Kappler, ${ }^{\|}$Barry P Rosen, ${ }^{\S}$ Andrew A

3 Meharg ${ }^{\perp}$

$4 \dagger$ Key Laboratory of Urban Environment and Health, Institute of Urban Environment,

5 Chinese Academy of Sciences, Xiamen, China

$6 \quad$ State Key Laboratory of Urban and Regional Ecology, Research Center for

7 Eco-Environmental Sciences, Chinese Academy of Sciences, Beijing, China

8 "Geomicrobiology, Center for Applied Geosciences, University of Tübingen,

9 Tübingen 72076, Germany

$10 \S$ Department of Cellular Biology and Pharmacology, Herbert Wertheim College of

11 Medicine, Florida International University, Miami, FL 33199, U.S.A.

$12 \perp$ Institute for Global Food Security, Queen's University Belfast, Belfast BT9 5HN,

13 United Kingdom

14

$15 \quad$ \#These authors contributed equally to the article.

16 *Address correspondence to Yong-Guan Zhu

17 Address: Institute of Urban Environment, Chinese Academy of Sciences, 1799 Jimei

18 Road, Xiamen 361021, China, Phone number: +86(0)592 6190997, Fax number:

19 +86(0)592 6190977, Email address: ygzhu@rcees.ac.cn 
The biotransformation of arsenic is highly relevant to the arsenic biogeochemical cycle. Identification of the molecular details of microbial pathways of arsenic biotransformation coupled with analyses of microbial communities by meta-omics can provide insights into detailed aspects of the complexities of this biocycle. Arsenic transformations couple to other biogeochemical cycles, and to the fate of both nutrients and other toxic environmental contaminants. Microbial redox metabolism of iron, carbon, sulfur and nitrogen affects the redox and bioavailability of arsenic species. In this critical review we illustrate the biogeochemical processes and genes involved in arsenic biotransformations. We discuss how current and future metagenomic-, metatranscriptomic-, metaproteomic-, and metabolomic-based methods will help to decipher individual microbial arsenic transformation processes, and their connections to other biogeochemical cycle. These insights will allow future use of microbial metabolic capabilities for new biotechnological solutions to environmental problems. To understand the complex nature of inorganic and organic arsenic species and the fate of environmental arsenic will require integrating systematic approaches with biogeochemical modeling. Finally, from the lessons learned from these studies of arsenic biogeochemistry, we will be able to predict how the environment changes arsenic, and, in response, how arsenic biotransformations change the environment. 


\section{Introduction}

Biogeochemical cycles are interconnected through redox reactions and other biotransformations. ${ }^{1}$ Biogeochemical processes such as the cycling of a particular element are likely to be mediated by multiple microbes and are often linked to other biogeochemical processes. For example, redox changes of arsenic are mediated by diverse arsenate (As(V))-reducing and arsenite (As(III))-oxidizing microbes. Arsenic biogeochemical cycling is often coupled to the cycling of iron $(\mathrm{Fe}),{ }^{2}$ carbon $(\mathrm{C})^{3}$ and nitrogen $(\mathrm{N}),{ }^{4}$ and to the dynamics of elements/ions associated with the arsenic redox cycle, such as sulfur (S). ${ }^{5}$ Coupling of biogeochemical cycles has recently received attention. The study of coupled biogeochemical cycles offers a scientific basis for major current environmental problems. ${ }^{6}$

The proteins catalyzing physiological processes in living organisms are influenced by geological, physical and chemical forces and therefore continuously evolve and redistribute chemical species involved in biogeochemical cycles. Genetic analysis is the key to understand the arsenic biogeochemical cycle. Once the genes associated with the reactions and the environmental signals that affect gene expression are understood, we will be able to predict how microbial metabolism influences arsenic biogeochemical cycling. In this review, we focus on the known genes involved in arsenic biotransformations and the effect of other elements on arsenic biogeochemistry. We highlight the effects of other elements on arsenic metabolism and the current state of meta-omics research in microbial arsenic metabolism. Finally, we discuss how integration of meta-omics information into biogeochemical models can allow us to predict the possible biotransformation of other elements. 


\section{Arsenic metabolism: from genes to biogeochemical processes}

Organisms have evolved various strategies to transform arsenic for detoxification or energy metabolism. ${ }^{7}$ An overview about the enzymatic pathways for arsenic biotransformations is presented in Figure 1, and related microbial genes are summarized in Table 1.

\subsection{The arsenic redox cycle}

The earliest microorganisms evolved in an anoxic environment, where the predominant arsenic species was most probably reduced As(III), with little oxidized As(V). The physiological activities of the earliest microorganisms were, therefore, largely driven by anaerobic metabolic processes, ${ }^{8}$ and we propose that As(III) bioavailability was a driving force for the evolution or acquisition of genes encoding anaerobic respiratory pathways. ${ }^{33}$ For example, the photosynthetic purple sulfur bacterium Ectothiorhodospira PHS-1 carries out anoxygenic photosynthesis using $\mathrm{As}(\mathrm{III})$ as an electron donor in the light ${ }^{34,35,36}$ and uses $\mathrm{As}(\mathrm{V})$ as an electron acceptor in the dark. ${ }^{37}$ The chemolithoautotrophic As(III)-oxidizer Alkalilimnicola ehrlichii MLHE-1 utilizes As(III) as an electron donor and nitrate as an electron acceptor in energy-generating respiratory chains. ${ }^{38}$ Microorganisms with similar metabolic versatility probably evolved quite early. These microbes could cope with extreme growth conditions, such as high concentrations of As(III) or low oxygen, similar to those that existed in an primordial anoxic biosphere.

Since As(III) was probably the primary bioavailable arsenic species on the early anoxic Earth, it was the inevitable choice for organisms to utilize As(III) as an electron donor to produce energy. ${ }^{39} \mathrm{As}$ (III) oxidation is catalyzed by the enzyme As(III) oxidase, which is composed of two different subunits, a large subunit $(\alpha)$ having molybdopterin and a $[3 \mathrm{Fe}-4 \mathrm{~S}]$ cluster (AioA) and a smaller subunit $(\beta)$ 
incorporating a Rieske-type [2Fe-2S] cluster (AioB). ${ }^{40}$ The cluster of aioA and aioB genes (aio operon) usually consists of aioS and aioR genes, encoding for a two-component signal transduction pair, AioS (sensor histidine kinase)/AioR (transcriptional regulator), which regulates expression of aio genes via recognizing As(III). ${ }^{9}$ The operon sometimes has an aioX gene that encodes an As(III)-binding protein involved in As(III)-based signaling and regulation of As(III) oxidation, ${ }^{12}$ a cytC gene encoding a cytochrome $\mathrm{c}$ that is required for efficient As(III) oxidation in Ochrobactrum tritici SCII24, ${ }^{41}$ or a moeA gene encoding MoeA protein that synthesizes the molybdenum cofactor of AioAB oxidase. ${ }^{9}$ Recently, a new type of As(III) oxidase, ArxA that exhibited both As(V) reductase and As(III) oxidase activities in vitro, ${ }^{10}$ was identified in A. ehrlichii MLHE-1. ${ }^{42}$ In Ectothiorhodospira sp. PHS-1 these genes code for As(III) oxidation coupled to photosynthesis.${ }^{35,}{ }^{11}$ In addition to $\operatorname{arx} A$, the MLHE-1 and PHS-1 arx operons, contain four other genes arxB2, $\operatorname{arx} B, \operatorname{arx} C$, and $\operatorname{arx} D$, that encode two proteins with [4Fe-4S] centers, a membrane anchoring and quinol oxidoreductase subunit and a TorD-like molybdoenzyme chaperone respectively. ${ }^{11}$ An adjacent and divergent gene cluster, arxXSR, encodes putative regulatory proteins, a periplasmic substrate-binding protein specific for phosphate (ArxX), a two-component histidine kinase sensor (ArxS), and a response regulator (ArxR). ${ }^{11}$ ArxA has higher sequence similarity to the ArrA subunit than to AioA, and fills the phylogenetic gap between As(III) oxidases and As(V) reductases. 42,11

Note that $\mathrm{As}(\mathrm{III})$ oxidation by anaerobes would have produced $\mathrm{As}(\mathrm{V})$ in the absence of an oxygen-containing atmosphere, which opened a niche for $\mathrm{As}(\mathrm{V})$-respiring microbes prior to the Great Oxidation Event (GOE). ${ }^{33}$ Dissimilatory As(V)-respiring prokaryotes (DARPs) evolved pathways to take advantage of the 
appearance of $\mathrm{As}(\mathrm{V})$ as a terminal electron acceptor. This new energy-generating respiratory chain utilized the respiratory $\mathrm{As}(\mathrm{V})$ reductase, $\mathrm{Arr} A B$, that reduce the less toxic $\mathrm{As}(\mathrm{V})$ to the more toxic and potentially more mobile $\mathrm{As}(\mathrm{III}) .{ }^{40,43,44} \mathrm{ArrAB}$ is a heterodimer consisting of a large catalytic subunit (ArrA) and a small subunit (ArrB). ${ }^{15,16}$ The arr operon also includes $\operatorname{arr} C$, arrD, arrS, and $\operatorname{arrR}$. Their gene products are ArrC, a membrane-bound $\mathrm{As}(\mathrm{V})$ reductase subunit, $\mathrm{ArrD}$, a $\mathrm{As}(\mathrm{V})$ reductase chaperon, ArrS, a sensor histidine kinase and ArrR, a transcriptional regulator respectively. ${ }^{17} \mathrm{~A}$ phylogenetic analysis was conducted to search for molybdenum-bis (pyranopterin guanine dinucleotide)-containing catalytic subunits of representative enzymes. This complex iron sulfur molybdoenzyme family includes Arr, Aio, Arx, polysulfide reductase, and nitrate reductase. The results indicate that Arr clusters most likely evolved from polysulfide reductases. ${ }^{17}$

After the GOE, As(III) in oceans mostly oxidized to As(V), a new environmental toxin. As(V) enters the cells of most organisms adventitiously via phosphate uptake systems. ${ }^{45}$ As a consequence, early life had to evolve novel strategies for coping with new (potentially toxic) arsenic species. As described in more detail below, nearly every extant microbe has ArsB or Acr3 efflux permeases for As(III) detoxification, so it is reasonable to assume that organisms that arose before the GOE already had an As(III) efflux system. When As(V) became the predominant soluble species, all cells had to do was to reduce As(V) to As(III), the substrate of ArsB or Acr3, and they would become resistant to $\mathrm{As}(\mathrm{V})$. A number of independently-evolved $\mathrm{As}(\mathrm{V})$ reductases arose in a variety of organisms using a small molecular mass protein $\mathrm{As}(\mathrm{V})$ reductases (one of several types of ArsC or Acr2 reductases). The ArsC system conferred by the ars operon is the most well studied mechanism of arsenic detoxification and resistance (for details see the previous review). ${ }^{18}$ Most recently, a 
glutathione S-transferase B (GstB) was found to mediate an alternate pathway which conferred $\mathrm{As}(\mathrm{V})$ resistance to $E$. coli mutant cells lacking arsC by directly reducing $\mathrm{As}(\mathrm{V})$ to $\mathrm{As}(\mathrm{III}) .{ }^{21}$ These enzymes all use small molecule proteins such as glutaredoxin (Grx) or reduced glutathione (GSH) coupled to thioredoxin (Trx) as electron donor. The Acr2 reductases evolved from proteins that incorporated the phosphate binding loop of phosphorprotein tyrosine phosphatases related to the cell phosphatase CDC25. ${ }^{46}$ These phosphatase can be converted into As(V) reductases by just a few mutations, ${ }^{47}$ indicating a facile evolutionary path.

\subsection{The arsenic methylation cycle}

In addition to oxidation and reduction of inorganic arsenic species, pathways for biotransformation of arsenic, including methylation and demethylation, organoarsenical degradation, evolved in early organisms. Interest in arsenic biomethylation began in 1800's with the observation that inorganic arsenic compounds used as wallpaper pigments were converted into Gosio gas (trimethylarsine) by fungi. More recent reports of methylated arsenical showed that arsenic methylation was widespread in the environment and detected in bacteria, ${ }^{48}$ cyanobacteria, ${ }^{49}$ algae, ${ }^{23}$ protozoa. ${ }^{50}$ Arsenic methylation is a common stratagem to detoxify arsenic. The highly toxic trivalent products are rapidly oxidized nonenzymatically in air to the less toxic pentavalent methylated arsenic species. Also, gaseous end-products such as trimethylarsine will emit to air, thus removing the product. Methylation is catalyzed by the enzyme As(III) S-adenosylmethionine (SAM) methyltransferase (EC 2.1.1.137), designated as AS3MT in animals and as ArsM in microorganisms. Expression of typical prokaryotic and archaeal arsM genes are regulated by the As(III)-responsive transcriptional repressor ArsR, ${ }^{20}$ consistent with arsenic methylation being a detoxification pathway in the microbes. Expression of 
ars $M$ in some cyanobacteria appears to be constitutive, ${ }^{51}$ indicating that alternate detoxification pathways are used by microorganisms in which the expression of ars $M$ is not regulated. ${ }^{52}$

The degradation of environmental organoarsenicals has been documented for some time, ${ }^{53,54}$ while few molecular mechanisms for these reactions have been demonstrated. Recently, a two-step pathway of MSMA reduction and demethylation was elucidated. ${ }^{55}$ Although no reductases of pentavalent organoarsenicals have been identified as yet, the enzyme, ArsI, which catalyzes demethylation of trivalent organoarsenicals, was identified and characterized from the environmental isolate bacterium Bacillus sp. MD1 ${ }^{24}$ and from the cyanobacterium Nostoc sp. 7120. ${ }^{56}$ ArsI, a non-heme iron-dependent dioxygenase with C-As lyase activity, cleaves the C-As bond in MAs(III), trivalent roxarsone, and other trivalent aromatic arsenicals. Putative ArsI orthologs were found only in bacterial species, suggesting that alternate pathways of organoarsenical demethylation might exist in other organisms. ${ }^{24}$

\subsection{The organoarsenical cycle}

The arsenic concentration in seawater is around 1 to $2 \mu \mathrm{g}$ per liter, mainly inorganic arsenic that is usually transformed into complex organoarsenical compounds by marine organisms. ${ }^{57}$ Arsenosugars, first identified in 1981, ${ }^{58}$ are commonly detected water-soluble arsenic species present in marine algae; arsenobetaine is the most abundant arsenic species in the majority of marine animals. ${ }^{57}$ More complex organoarsenicals have been identified with the improvement of analytical techniques in recent years. Since the structure of an arsenosugar phospholipid (AsPL) from a brown alga Undaria pinnatifida was first identified, ${ }^{59}$ AsPL has been found in algae 60 and cyanobacteria. ${ }^{61}$ Arsenic-containing fatty acids (AsFA) that were first identified in cod liver oil ${ }^{62}$ have now been found in algae ${ }^{63}$ and various fish species. 
64, 65 AsHC that were first reported in capelin ${ }^{66}$ have been detected in fish ${ }^{64,65}$ and algae. ${ }^{60}$ A new class of arsenolipids, trimethylarsenio fatty alcohols (TMAsFOH), was reported in Capelin oil. ${ }^{67}$ Two new groups of arsenolipids, arsenic-containing phosphatidylcholines (AsPC) and arsenic-containing phosphatidylethanolamine (AsPE) from herring caviar, were characterized. ${ }^{68}$ In total, more than 20 arsenosugars and 70 arsenolipids have been identified in marine organisms that live in low phosphate and high salt environments. These organoarsenicals are not toxic for the marine plants and animals, but their function in these marine organisms is not known. Phytoplankton can substitute sulfur- and nitrogen-containing membrane lipids for membrane phospholipids, ${ }^{69}$ arsenolipids might be used in membranes in place of phospholipids due to the more similarity of $\mathrm{As}(\mathrm{V})$, than sulfate and nitrate, to inorganic phosphate. Thus As(V) could be used as a phosphate-sparing substitute in phosphate-limiting environments. A recent study on Ectocarpus siliculosus that was found to produce more arsenosugar phospholipids under low-phosphate than under normal phosphate conditions ${ }^{70}$ supports this hypothesis.

These organoarsenicals may be toxic to organisms that cannot biosynthesize them. In vitro toxicological characterization of three arsenic-containing hydrocarbons showed that cytotoxicity of the arsenic-containing hydrocarbons was comparable to that of As(III) for cultured human bladder and liver cells, ${ }^{71}$ and arsenolipids were metabolized by humans to dimethylated arsenical species (DMAs) and other small molecular arsenic compounds, then excreted in the urine. ${ }^{72,73}$

Although several potential pathways have been proposed for the synthesis of complex organoarsenicals, ${ }^{8}$ few genes involved in these biotransformation have been identified. Even less is known about the degradation of these organoarsenicals, and more studies are needed on this front. 


\subsection{The arsenic thiolation cycle}

217 Thioarsenates $\left(\mathrm{H}_{3} \mathrm{AsS}_{\mathrm{n}} \mathrm{O}_{4-\mathrm{n}}\right)$ are the dominant arsenic species in alkaline, arsenic-rich, 218 sulfidic environments. These play a significant role in the arsenic biochemical cycle in 219 sulfidic geothermal environments. ${ }^{74,}$ 75, 76 Thioarsenates are transformed to As(V) 220 and/or As(III) via exposing to oxidizing agents or increased $\mathrm{pH},{ }^{77}$ by biological 221 conversion by sulfur-oxidizing bacteria, ${ }^{75},{ }^{78}$ or by abiotic decomposition 222 (desulfidation) with subsequent biological oxidation. ${ }^{77,} 79$ Thioarsenates contain 223 reduced $\mathrm{S}^{2-}$ and oxidized $\mathrm{As}(\mathrm{V})$. They can serve both as electron donors and electron 224 acceptors. For example, monothioarsenate can be used as an electron donor by 225 Thermocrinis ruber OC 14/7/2, ${ }^{80}$ and for anoxygenic photosynthesis by phototrophic 226 purple sulfur bacteria growing in an alkaline environment. ${ }^{81}$ Recently, the

227 haloalkaliphilic bacterium MLMS-1 can grow chemolithotrophically by oxidizing the

$228 \mathrm{~S}^{2-}$ of monothioarsenate to $\mathrm{S}^{0}$ or $\mathrm{SO}_{4}{ }^{2-}$, while concurrently reducing $\mathrm{As}(\mathrm{V})$ to $\mathrm{As}(\mathrm{III})$.

22978 In summary, various microbes have evolved to utilize thioarsenates that are 230 widespread in sulfidic environments.

$231 \quad 2.5$ Arsenic efflux pathways

232 The best way to deal with toxic arsenicals in cells is acquisition of an efficient efflux 233 system. As(III) efflux systems have been intensively studied in both microbes and 234 higher organisms. ${ }^{82,83} \mathrm{As}(\mathrm{III})$ efflux in most bacteria is mediated by ArsB in an 235 energy-dependent process, driven in Staphylococcus aureus by the membrane 236 potential ${ }^{84}$ and in E. coli by ATP hydrolysis that ArsA binds to ArsB to an 237 ATP-driven arsenic-specific pump. ${ }^{26}$ In the legume symbiont S. meliloti, an 238 aquaglyceroporin (AqpS), instead of ArsB, has been identified to extrude As(III) from 239 cells. ${ }^{27}$ Acr3 has been shown to be an As(III)-efflux transporter in both bacteria and 240 yeast, and provides a pathway for As(III) extrusion from cells. ${ }^{19}$ In fact, genes for 
Acr3 are more wide-spread in bacteria and archaea than are $\operatorname{ars} B$ genes. The cytosolic As(III)/glutathione complex sequestered into vacuoles by an ABC-type transporter,

243 Ycflp (yeast cadmium factor protein), is the second pathway for As(III) 244 detoxification in yeast S. cerevisiae. ${ }^{28}$

245 Moreover, a novel mechanism for As(V) resistance was identified in a variety of 246 microbes including Pseudomonas aeruginosa. ${ }^{29}$ In these bacteria there are two genes 247 that always go together, one encoding a typical glyceraldehyde-3-phosphate 248 dehydrogenase (GAPDH) and the second one, called ars , that encodes an 249 organoarsenical efflux permease (ArsJ). GAPDH uses As(V) and glyceraldehyde 250 3-phosphate to form the extremely unstable organoarsenical 251 1-arsenso-3-phosphoglycerate, which is extruded from cells by ArsJ and immediately 252 breaks down into $\mathrm{As}(\mathrm{V})$ and 3-phosphoglycerate. The net reaction is effectively $\mathrm{As}(\mathrm{V})$ 253 extrusion, and the coupled reaction confers $\mathrm{As}(\mathrm{V})$ resistance to these microbes, the 254 only known efflux pathway for As(V). Meanwhile the bacterial permease, ArsP, from 255 Campylobacter jejuni, was demonstrated to be an efflux system specific for trivalent 256 organoarsenicals. ${ }^{30}$ It is more selective for the ancient organoarsenical MAs(III) than 257 for the recently anthropogenically-developed antimicrobial aromatic arsenical growth 258 promoters such as trivalent roxarsone. More and more arsenic reductases and trivalent 259 arsenic-specific transporters identified show that arsenic reduction and efflux play an 260 important role in arsenic biogeochemical cycling.

\section{Coupling of arsenic biogeochemical cycling to other elements}

263 Any biogeochemical process, such as the cycling of a particular element, is likely to 264 be mediated by more than one organism, and often linked to other fundamental 265 biogeochemical processes. Arsenic biotransformations are often coupled to the 
cycling of C, Fe, S and N. ${ }^{85,2,86}$ The effect of turnover of these elements on microbes

267 involved in arsenic biogeochemical cycling is summarized in Figure 2 which contains 268 data based on previous studies ${ }^{8,87,88,89}$ and as described below.

\section{3.1 The effects of iron on arsenic biogeochemical cycling}

270 The chemical speciation of arsenic and arsenic mobility in natural environments are 271 strongly dependent on redox potential and $\mathrm{pH}$. Under oxic conditions, $\mathrm{As}(\mathrm{V})$ is the 272 predominated arsenic species, present mainly as $\mathrm{H}_{2} \mathrm{AsO}_{4}{ }^{-}$at acid $\mathrm{pH}$ or $\mathrm{HAsO}_{4}{ }^{2-}$ at 273 alkaline $\mathrm{pH}$. In anoxic environments, arsenic occurs primarily as reduced As(III) $274\left(\mathrm{As}(\mathrm{OH})_{3}\right.$ at neutral $\mathrm{pH}$ or $\mathrm{H}_{2} \mathrm{AsO}_{3}{ }^{-}$at alkaline $\left.\mathrm{pH}\right)$, and more mobile than $\mathrm{As}(\mathrm{V}) .{ }^{90}$ 275 Moreover, $\mathrm{pH}$ will impact arsenic interactions with $\mathrm{Fe}$, the sorption of $\mathrm{As}(\mathrm{V})$ onto 276 amorphous iron oxide and goethite is higher than that of As(III) below pH 5-6, As(V) 277 and $\mathrm{As}(\mathrm{III})$ sorption onto iron oxide are both relatively high at neutral $\mathrm{pH}, \mathrm{As}(\mathrm{III})$ is 278 more easily adsorbed to iron oxide than $\mathrm{As}(\mathrm{V})$ above $\mathrm{pH} 7-8 .{ }^{91}$ interactions between the arsenic and Fe cycles including mineral formation, transformation, dissolution and redox reactions. ${ }^{89,}$ 92, 93, 94 Previous studies from our laboratory showed that Fe plaque consisting of Fe(III) (oxyhydr)oxides, which was induced artificially through adding ferrous iron in solution to paddy soils, has high affinity for $\mathrm{As}(\mathrm{V})$, and reduced arsenic uptake by rice. ${ }^{95,96,97}$

287 Dissimilatory reduction of $\mathrm{Fe}(\mathrm{III})$ (oxyhydr)oxides to $\mathrm{Fe}(\mathrm{II})$ by dissimilatory 288 iron-reducing bacteria (DIRB) can result either in the release of $\mathrm{As}(\mathrm{V})$ from poorly 289 crystalline or more crystalline ferric minerals as well as from sorption sites within

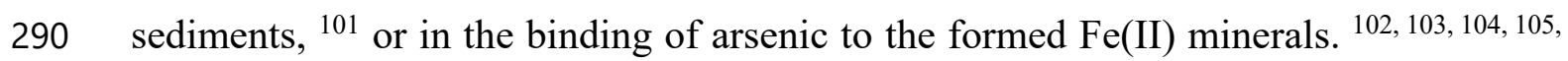


106 DIRB are commonly present in rice paddy soil, and mediate dissimilatory reduction of $\mathrm{Fe}(\mathrm{III})$ on the rice root-plaque. ${ }^{107} \mathrm{~A}$ study on the role of DIRB in arsenic release under a range of biogeochemical regimes indicated that $\mathrm{Fe}(\mathrm{III})$ reduction was stimulated by addition of acetate as a potential electron donor that resulted in a marked increase in the number of DIRB, reduction of $\mathrm{As}(\mathrm{V})$ to $\mathrm{As}(\mathrm{III})$, and arsenic release after Fe(III) reduction. ${ }^{100}$ If DARPs were used as Fe(III)-reducers, Shewanella sp. ANA-3 ${ }^{108}$ or Sulfurospirillum barnesii ${ }^{109}$ could release both As(III) and Fe(II) from ferrihydrite containing $\mathrm{As}(\mathrm{V})$ by reducing solid-phase $\mathrm{As}(\mathrm{V})$ and $\mathrm{Fe}(\mathrm{III})$. Eventually, most of the ferrihydrite matrix was liberated as Fe(II) and As(III) if sufficient organic electron donor was present. ${ }^{110}$ There is more aluminum in the crust than iron. However, S. barnesii does not reductively dissolve the As(V)-aluminum hydroxide precipitate, ${ }^{111}$ so we did not include a detailed description of the effect of aluminum on arsenic biogeochemical cycling.

In addition to $\mathrm{Fe}(\mathrm{III})$ reduction that has the potential to mobilize or immobilize arsenic depending on geochemical conditions that lead to the formation of either dissolved $\mathrm{Fe}^{2+}$ or $\mathrm{Fe}(\mathrm{II})$ minerals, the formation of $\mathrm{Fe}(\mathrm{III})$ minerals under Fe(II)-oxidizing conditions has the potential to significantly immobilize arsenic and thus to lower its bioavailability. ${ }^{112,} 113$ In particular for nitrate-reducing Fe(II)-oxidizing bacteria it has been shown that they form poorly soluble Fe(III) minerals and efficiently co-precipitate arsenic (Figure 2). 112, 113, 114 Besides nitrate-dependent $\mathrm{Fe}(\mathrm{II})$ oxidation, also microaerophilic $\mathrm{Fe}(\mathrm{II})$ oxidation has the potential to influence arsenic mobility and could even be used in biotechnical applications for arsenic removal, e.g. in drinking water filters ${ }^{115}$ although it has been 314 shown that in commercial drinking water filters the formation of iron biominerals by 315 Fe(II)-oxidizing bacteria lowers arsenic removal from the water. ${ }^{116}$ Moreover, a 
thermo-acidophilic iron-oxidizing archaeon Acidianus brierleyi, has been used to immobilize As(III) in the copper refinery process by producing thermodynamically stable crystalline scorodite $\left(\mathrm{FeAsO}_{4} \cdot 2 \mathrm{H}_{2} \mathrm{O}\right) \cdot{ }^{117}$

\subsection{The effects of sulfur on arsenic biogeochemical cycling}

More than 200 different arsenic-containing minerals have been found in the Earth's crust, and $20 \%$ are sulfides and sulfosalts. ${ }^{118}$ The behavior of arsenic is affected by abiotic or biological redox of sulfur, which can either release or immobilize arsenic. 114, 119 Abiotic sulfide, a strong reductant under sulfate-reduced conditions, plays a critical role in arsenic solubility by forming pyrite $\left(\mathrm{FeS}_{2}\right)$, realgar (AsS), orpiment $\left(\mathrm{As}_{2} \mathrm{~S}_{3}\right),{ }^{120}$ arsenopyrite $(\mathrm{FeAsS}),{ }^{121}$ or by reducing $\mathrm{As}(\mathrm{V}) .{ }^{122}$

In addition to abiotic factors, sulfate-reducing bacteria (SRB) also cause dramatic changes in $\mathrm{Fe}$, sulfide and arsenic species by generating hydrogen sulfide ${ }^{123}$ or elemental sulfur from sulfate, ${ }^{5}$ or by localized reprecipitation of released arsenic as $\mathrm{As}_{2} \mathrm{~S}_{3}{ }^{124}$ or FeAsS, which have low solubility. ${ }^{125}$ Sulfur-oxidizing bacteria have the potential to immobilize arsenic by using free or arsenic-bound sulfur as an electron donor to directly or indirectly transform $\mathrm{As}(\mathrm{III})$ and thioarsenates to $\mathrm{As}(\mathrm{V}),{ }^{75}$ or reduce $\mathrm{As}(\mathrm{V}){ }^{126,}{ }^{127}$ In brief, transformations involving sulfur have the potential to significantly impact the fate of environmental arsenic.

\subsection{The effects of $\mathrm{N}$ on arsenic biogeochemical cycling}

Nitrate is an ecologically significant oxidant that can support microbial oxidation of As(III) in the absence of oxygen. The first evidence that microbes are capable of linking anoxic As(III) oxidation to denitrification came from a field study in anoxic lake water columns. ${ }^{4}$ The absence or presence of nitrate affected the redox state of arsenic. As(III) was present where nitrate was depleted, but As(V) was the dominant species during anoxic nitrate-rich periods. Subsequently, a nitrate-dependent As(III) 
oxidation bacterium A. ehrlichi strain MLHE-1 was found to be capable of coupling

342 As(III) oxidation with partial denitrification of nitrate to nitrite. ${ }^{38,128}$ Two other

343 anoxic chemolithoautotrophic strains, Azoarcus strain DAO1 and Sinorhizobium

344 strain DAO10, were able to oxidize As(III) and fix $\mathrm{CO}_{2}$ via complete denitrification of

345 nitrate to dinitrogen gas. ${ }^{129}$ Biological nitrate-dependent As(III) oxidation is 346 widespread in the environment, and potentially plays a significant role in arsenic 347 biogeochemical cycling. ${ }^{130}$

As mentioned above, nitrate also influences the bioavailability and mobility of arsenic indirectly by linking nitrate reduction to Fe(II) oxidation. Previous studies showed tight coupling between N, Fe, and arsenic in paddy soil. ${ }^{85}$ Addition of nitrate reduced arsenic uptake by rice probably because i) the nitrate inhibited/reduced $\mathrm{Fe}(\mathrm{III})$ reduction leading to less arsenic mobilization and ii) nitrate-dependent $\mathrm{Fe}(\mathrm{II})$-oxidizing bacteria stimulated $\mathrm{Fe}(\mathrm{II})$ oxidation, which led to arsenic co-precipitation with Fe(III) minerals in soil. Nitrate strongly affects arsenic cycling under anoxic conditions in nitrate-rich Upper Mystic Lake by microbially catalyzing $\mathrm{As}(\mathrm{III})$ to more particle-reactive $\mathrm{As}(\mathrm{V})$ and oxidizing $\mathrm{Fe}(\mathrm{II})$ to arsenic-sorbing particulate ferric oxides. ${ }^{4}$ Microbial nitrate-dependent $\mathrm{Fe}(\mathrm{II})$ oxidation in groundwater, ${ }^{131}$ freshwater sediments ${ }^{132}$ and marine sediments ${ }^{133}$ has the potential to

359 contribute to the reduction of arsenic mobility in various ecosystems.

\subsection{The effects of organic matter on arsenic biogeochemical cycling}

361 Natural organic matter (NOM) is widely distributed in the environment. NOM 362 consists of heterogeneous mixtures of organic compounds with various structural and

363 functional properties, ${ }^{134}$ that influence the fate of arsenic by competitive adsorption 364 and redox reactions, 135, 136, 137 and by formation of arsenic-bearing organic-metal-complexes and mineral colloids. 138, 139 NOM molecules have 
combinations of carboxylic, amino, sulfhydryl, hydroxyl, esteric, phenolic, nitroso, 367 and other functional groups. ${ }^{140}$ They are considered to be an efficient geochemical 368 trap for arsenic both under oxic and reducing conditions. Whereas $\mathrm{As}(\mathrm{V})$ is 369 immobilized by binding to protonated amino groups of $\mathrm{NOM}^{3}$ or a nucleophile 370 substitution reaction between $\mathrm{As}(\mathrm{V})$ and phenolic $\mathrm{OH}$ groups of $\mathrm{NOM},{ }^{141} \mathrm{As}(\mathrm{III})$ is 371 associated with NOM via phenolic $\mathrm{OH}$ or carboxyl groups of NOM by H-bonding, 372 hydrophobic As(III)-NOM interactions, ${ }^{141}$ or via ternary As(III)-Fe(III)-NOM complexes that form bridges between Fe(III), arsenic oxyanions and the functional entities of NOM. ${ }^{142}$ In contrast, under sulfate-reducing conditions, the formation of a trigonal-pyramidal complex between As(III) and sulfhydryl groups of NOM could potentially be a sequestration mechanism for arsenic. ${ }^{143}$

Organic matter could also change the fate of arsenic by influencing microbial communities or activities. ${ }^{144,145,146} \mathrm{NOM}$ is thought to drive the reductive dissolution of Fe(III) (oxyhydr)oxides, thereby causing redox transformations of $\mathrm{As}(\mathrm{V})$ to $\mathrm{As}(\mathrm{III})$ 380 and facilitate arsenic release. ${ }^{147}$ In addition to the reductive dissolution of arsenic-bearing Fe(III) (oxyhydr)oxide phases, studies have revealed that addition of organic matter to paddy soil significantly increased arsenic methylation and volatilization. ${ }^{148}$ Application of rice straw into soil increased arsenic accumulation in rice by influencing microbial processes involved in arsenic redox. ${ }^{149}$ Humic acids, which are forms of NOM, can reduce As(V). ${ }^{150,151,152}$ Small organic molecules, including lactate, pyruvate, fumarate, malate, succinate, butyrate, citrate, acetate, glycerol, ethanol, and formate, can be used an electron donor by DARPs for As(V) reduction. ${ }^{153,154,155,156}$ Desulfosporosinus sp. Y5 has been found 389 to couple even complex aromatic substrates such as phenol, syringic acid, benzoate, 390 ferulic acid, and toluene, to $\mathrm{As}(\mathrm{V})$ reduction. ${ }^{157}$ In fact, some DARPs can also respire 
391 sulfate, selenite, $\mathrm{Fe}(\mathrm{III})$, thiosulfate, nitrate, or nitrite. ${ }^{153,154}$ This diversity of electron 392 donors and acceptors may be of benefit to microbes grown in environments where $\mathrm{Fe}$, $393 \mathrm{~N}, \mathrm{~S}$, or C coexist with arsenic.

394 Apart from iron oxides and organic materials, silicon significantly decreased 395 As(III) concentration, but increased the concentration of DMAs in both the vegetative 396 and reproductive tissues of rice. ${ }^{158}$ In brief, in addition to biological transformations, 397 other inorganic elements, compounds/minerals and physico-chemical properties 398 interact with arsenic in the environment. Coupling of arsenic with other elements 399 makes it necessary to consider genes involved in cycling of other elements, such as Fe,

$400 \mathrm{~N}, \mathrm{~S}$, and $\mathrm{C}$ when studying the arsenic biogeochemical cycling. ${ }^{2,87,88}$

Known genes involved in arsenic biotransformation are readily determined in 402 pure cultures. However, in the field, these genes cannot easily be quantified in 403 bacterial communities with a limited number of primers, even though As(V)-reducing and As(III)-oxidizing bacteria are widely distributed in the environment. ${ }^{159,160,161}$ In 405 addition, the speciation, fate and biogeochemical transformation processes of arsenic 406 in the environment are much more complex than under laboratory conditions. ${ }^{162,163}$ It 407 is therefore necessary to apply more systematic and more comprehensive approaches 408 such as metagenomics, metatranscriptomics, metaproteomics, and metabolomics to 409 understand interactions between environmental microbes. These approaches will take 410 into account local geochemical surroundings and neighboring organisms by analyzing 411 DNA, RNA, proteins, and metabolites extracted directly from environmental samples.

\subsection{Metagenomics}


416 Metagenomics provides an inestimable window into the microbial world by 417 characterizing microorganisms involved in difficult-to-elucidate but important 418 biochemical pathways, as the overwhelming majority of microbes in the environment 419 cannot be cultured in the laboratory. From a metagenomic library two 420 arsenic-resistant bacteria and one novel $\mathrm{As}(\mathrm{V})$ resistance gene $(\operatorname{ars} N)$, which encodes 421 a protein similar to acetyltransferases, were identified. ${ }^{22}$ Xiao et al applied 422 metagenomic techniques to analyze genes associated with arsenic transformation. 423 They analyzed five low-arsenic paddy soils using high-throughput sequencing and 424 constructed a protein database of arsenic metabolizing genes. Their analysis shows 425 that arsenic metabolism genes are ubiquitous and abundant, even in low-arsenic 426 environments. ${ }^{164}$ Metagenomics was also used to unravel the correlations between the 427 microbes and arsenic transformation in different niches. 165, 166, 167, 168, 169 Although 428 metagenomics provides taxonomic and functional profiles of a microbial community, 429 it does not demonstrate the levels of expression of the genes nor their physiological 430 activity. ${ }^{170}$ Therefore, metatranscriptomics is needed to delineate the active functional 431 genes and communities.

\section{$432 \quad 4.2$ Metatranscriptomics}

433 Metatranscriptomics offers novel insights into the expression of functional genes and 434 microbial activities of complex microbial communities at a specific moment or under 435 specific environmental conditions by sequencing the total mRNAs extracted from 436 natural microbial communities. Functional metatranscriptomics has potential for 437 isolation and characterization of novel genes involved in heavy metal transformation.

$438{ }^{171}$ Metatranscriptomics enhances our understanding of microbial responses to their 439 environment ${ }^{172}$ and the functional profile of a microbial community. ${ }^{173}$ Recently, a 440 transcriptomics meta-analysis was used to unravel the effect of As(III) on the 
symbiotic interaction between the model legume Medicago truncatula and its symbiont Ensifer (syn. Sinorbizobium) medicae MA11. ${ }^{174}$ This study identified the adaptive responses of the bacterial symbiont to arsenic exposure. This metatranscriptomic approach will be useful to study how microbes regulate their genes to adapt to the changes in environmental conditions, particularly arsenic concentrations. ${ }^{175}$ The correlation between mRNA and protein inventories in environmental microbial communities is low when environmental conditions change rapidly. mRNA inventories respond rapidly and sensitively to the shift, while changes in protein inventories are slow. ${ }^{176}$ As a consequence, microbial metaproteomics and metabolomics had to be used to identify the repertoire of proteins and small molecular metabolites that microbes use to adapt to complex and dynamic environments. In this way, the metabolic activities of a microbial community in specific environments at the moment of sampling could be elucidated. ${ }^{170}$

\subsection{Metaproteomics and metabolomics}

Metaproteomics and metabolomics are the comprehensive methods by which proteins produced by microbes and metabolites released by microorganisms into the environment are characterized and quantified using a combination of liquid or gas chromatography-based separations and mass spectrometry-based identification techniques. ${ }^{177,178}$ The study of microbial proteome and metabolome can provide valuable information about the function of microbial communities and the interactions of the microbial communities with the environment. ${ }^{179,180}$ When the diversity of arsenic-adapted prokaryotic communities in mildly arsenic-contaminated sediments was analyzed using meta-proteomic and 16S rRNA amplification, the results indicated that the data sizes provided by metaproteomics are less than those provided by metagenomics and metatranscriptomics. ${ }^{181}$ So far, metabolomics has been used 
mainly to analyze low molecular mass metabolites within a tissue, biofluid, a cell or

467 cell compartment of an organism including plants, animals, bacteria, and humans 468 exposed to an environmental stressor. ${ }^{180}$ High-throughput metabolomics has been 469 applied to the analysis of metabolites in the liver of mice when co-exposed to high fat 470 and cholesterol diets and arsenic-contaminated drinking water. ${ }^{182}$ However, 471 application of metaproteomic and metabolomic techniques to real environment is 472 limited due to difficulties with amplification and the low quantities of extractable 473 proteins and metabolites because of the interferences with many components present 474 in complex environmental systems, such as soil. ${ }^{180,183}$

\section{$475 \quad 4.4$ Integrating meta-omic techniques}

476 From the above, meta-omics are key techniques in elucidating the dynamic and 477 complex interactions between microbial communities and the environment. 478 Integrating multiple meta-omic datasets will provide a complete exhibition from 479 genes to biogeochemical cycles. Metatranscriptomic and metagenomic techniques 480 were combined to detect large numbers of novel genes from complex marine 481 microbial communities. ${ }^{173}$ Datasets of meta-genomics were integrated with 482 metabolomics to reveal how a microbial community interacts with the environment 483 and responds to environmental parameters. ${ }^{184}$ Taken together, meta-omic 484 technologies offer an unprecedented opportunity to elucidate the functions of 485 microbes that are not readily cultured under normal laboratory conditions in 486 biogeochemical cycles.

487 Recently, "Arsenomics" was termed as an approach to focusing on the analysis 488 of alterations in transcriptome, proteome and metabolome occurring in microbes 489 exposed to arsenic. ${ }^{185,} 186$ With the application of meta-omics to environmental 
science, we believe that Arsenomics will evolve to include the analysis of metagenomic, metatranscriptomic, metaproteomic, and metabolomic changes in microbial communities from the real environment where they are exposed to arsenic.

\subsection{Integrating environmental meta-omics into biogeochemical models for} arsenic

Microbes are ubiquitous in diverse environmental niches including soil, oceans, sediments, freshwater environments, and inside the body of animals or plants, and exert great influence on biogeochemical cycles in these habitats. ${ }^{187}$ For example, microbes involved in arsenic transformation are ubiquitously distributed in paddy soils, resulting in various concentrations and percentage of inorganic and methylated arsenic species among different rice plants. ${ }^{188,189,190,191}$ Since higher plants appear not to methylate arsenic, ${ }^{192}$ microbial methylation is probably the primary source of methylated arsenic in plants, which occurs in soil prior to plant uptake.

In situ measurements or prediction of arsenic transformations contribute to analysis of the dynamics of arsenic and prediction of arsenic bioavailability. In situ measurements of $\mathrm{As}(\mathrm{V})$ reduction in Mono Lake, California (dissolved inorganic arsenic $\sim 200 \mu \mathrm{M})$, made with radiotracers $\left({ }^{73} \mathrm{As}\right.$ and $\left.{ }^{35} \mathrm{~S}\right)$ of mass balance considerations, revealed that $\mathrm{As}(\mathrm{V})$ reduction occurred in the monimolimnion waters with the highest rates between 18 and 19 meters (rate, $\sim 5.9 \mu \mathrm{M} /$ day) and sulfate reduction rates increased with depth at depths of 21 meters and below with the highest rates at 28 meters (rate, $\sim 2.3 \mu \mathrm{M} /$ day). ${ }^{193}$ The radioisotope method was further employed to examine the $\mathrm{As}(\mathrm{V})$ and sulfate reduction processes in sediments of two arsenic-rich soda lakes, Mono Lake (moderately salt, $\sim 90 \mathrm{~g} / \mathrm{L}$ ) and Searles Lake (saturated salt, $\sim 340 \mathrm{~g} / \mathrm{L}$ ). ${ }^{194}$ The rate constant $[\mathrm{k}]$ of $\mathrm{As}(\mathrm{V})$ reduction was 0.103 to $0.04 \mathrm{~h}^{-1}$ in Mono Lake and 0.012 to $0.002 \mathrm{~h}^{-1}$ in Searles Lake, and sulfate reduction 
515 was only detected in Mono Lake $\left(\mathrm{k}=7.6 \times 10^{4}\right.$ to $\left.3.2 \times 10^{-6} \mathrm{~h}^{-1}\right)$. Denatured gradient gel 516 electrophoresis (DGGE) of 16S rRNA genes amplified from Mono Lake and Searles

517 Lake sediment DNA indicated that microbial communities from two sediments were

518 distinct from each other. More arrA gene signal was found in Mono Lake than in

519 Searles Lake, where higher As(V) reduction activity was observed, due to PCR biases, 520 the presence of novel arrA genes, or higher expression of low-abundance arrA genes. $521 \quad 194$

522 Characterization of genes involved in arsenic biotransformation and application 523 of multiple meta-omics in environment analysis will lead to insights into the microbial 524 world, as limited information on functional genes cannot predict the status of arsenic 525 in the environment. The information of field/in situ characterization of functional 526 genes/functional microbial communities and biogeochemical fluxes should be 527 integrated into biogeochemical models to complete the transition from lab to the field, 528 from biochemistry to biogeochemistry, and from genes-genomics to microbial 529 communities. This integration will help to predict the dynamics of arsenic in the 530 environment, and to improve the effectiveness of mitigation technologies. Many 531 strategies have been developed to model low complexity environments. For example, 532 recent work integrating environmental genomics and qPCR in biogeochemical models 533 explored the nexus between microbial community and geochemisty in the Arabian 534 Sea oxygen minimum zone. ${ }^{195}$ Metabolic processes coupling C, N, and S 535 transformations in the Saanich Inlet oxygen-starved zone were integrated using a 536 biogeochemical model that integrates multi-omic information and geochemistry. ${ }^{196}$ 537 These studies indicated that such integrated modeling approaches can provide a novel 538 insight into microbial metabolic networks in water bodies, and pave a road for 539 prediction of elemental cycling. 
54155 Perspectives

542 In summary, as arsenic biotransformations are catalyzed by a suite of enzymes from

543 diverse environmental organisms, and these are coupled to biogeochemical cycles of

544 other elements such as Fe, S, and N. As more and more genomes are being sequenced,

545 more genes directly or indirectly involved in arsenic metabolism will be discovered

546 and characterized. With the development of new technologies, we anticipate rapid

547 advances in analytical chemistry, microbiology and genomics that will improve our

548 understanding of how microbial metabolic pathways contribute to and govern

549 complex environmental processes. In the future, integrating meta-omic datasets into

550 biogeochemical models will improve the ability of prediction and offer a deeper

551 insight into arsenic biogeochemical processes in diverse niches.

552 In future studies, it will be necessary to analyze the interaction between 553 organisms and the environment using additional meta-omics approaches at different 554 spatio-temporal scales. Geochemical analyses in combination with genetic analyses 555 will provide insights into the specific roles of the complex biochemical pathways in 556 the global arsenic biogeochemical cycle. More importantly, integrating modeling 557 approaches linking arsenic biogeochemical cycle with meta-omics data should be 558 developed to predict the dynamic of arsenic species in water, sediments and soils and 559 provide our society and authorities with the tools necessary for limiting arsenic 560 pollution, improving remediation and providing safe drinking water and food. 

technology Cooperation Program of China (2011DFB91710). BPR was supported by

NIH grants GM55425 and ES023779.

\section{Reference}

570 (1) Bashkin V N. Modern biogeochemistry; Springer Science \& Business Media, 2002.

571 (2) Oremland, R. S.; Stolz, J. F. The ecology of arsenic. Science (80). 2003, 300, 939-944 DOI: 10.1126/science. 1081903.

573

(3) Thanabalasingam, P.; Pickering, W. F. Arsenic sorption by humic acids. Environ. Pollut. (Series B) 1986, 12 (3), 233-246 DOI: 10.1016/0143-148X(86)90012-1.

(4) Senn, D. B.; Hemond, H. F. Nitrate controls on iron and arsenic in an urban lake. Science (80).

(5) Saalfield, S.; Bostick, B. Changes in iron, sulfur, and arsenic speciation associated with

(6) Finzi, A. C.; Cole, J. J.; Doney, S. C.; Holland, E. A.; Jackson, R. B. Research frontiers in the

(7) Mukhopadhyay, R.; Rosen, B. P.; Phung, L. T.; Silver, S. Microbial arsenic: from geocycles to genes and enzymes. FEMS Microbiol Rev 2002, 26, 311-325 DOI: 10.1111/j.1574-6976.2002.tb00617.x.

(8) Zhu, Y.-G.; Yoshinaga, M.; Zhao, F.-J.; Rosen, B. P. Earth Abides Arsenic Biotransformations. Annu. Rev. Earth Planet. Sci. 2014, 42 (1), 443-467 DOI: 10.1146/annurev-earth-060313-054942.

(9) Sardiwal, S.; Santini, J. M.; Osborne, T. H.; Djordjevic, S. Characterization of a

(10) Richey, C.; Chovanec, P.; Hoeft, S. E.; Oremland, R. S.; Basu, P.; Stolz, J. F. Respiratory family of molybdenum oxidoreductases. Environ. Microbiol. 2012, 14 (7), 1635-1645 DOI: 
10.1111/j.1462-2920.2012.02722.x.

600

601

602

603

604

605

606

607

608

609

610

611

612

613

614

615

616

617

618

619

620

621

622

623

624

625

626

627

628

629

630

631

632

633

634

635

636

637

638

(12) Liu, G.; Liu, M.; Kim, E. H.; Maaty, W. S.; Bothner, B.; Lei, B.; Rensing, C.; Wang, G.; McDermott, T. R. A periplasmic arsenite-binding protein involved in regulating arsenite oxidation. Environ. Microbiol. 2012, 14 (7), 1624-1634 DOI:

10.1111/j.1462-2920.2011.02672.x.

(13) Chen, J.; Bhattacharjee, H.; Rosen, B. P. ArsH is an organoarsenical oxidase that confers resistance to trivalent forms of the herbicide monosodium methylarsenate and the poultry growth promoter roxarsone. Mol. Microbiol. 2015, 96 (5), 1042-1052 DOI:

10.1111/mmi.12988.

(14) Xue, X. M.; Yan, Y.; Xu, H. J.; Wang, N.; Zhang, X.; Ye, J. ArsH from Synechocystis sp. PCC 6803 reduces chromate and ferric iron. FEMS Microbiol. Lett. 2014, 356 (1), 105-112 DOI: 10.1111/1574-6968.12481.

(15) Afkar, E.; Lisak, J.; Saltikov, C.; Basu, P.; Oremland, R. S.; Stolz, J. F. The respiratory arsenate reductase from Bacillus selenitireducens strain MLS10. FEMS Microbiol. Lett. 2003, 226 (1), 107-112 DOI: 10.1016/S0378-1097(03)00609-8.

(16) Krafft, T.; Macy, J. M. Purification and characterization of the respiratory arsenate reductase of Chrysiogenes arsenatis. Eur. J. Biochem. 1998, 255 (3), 647-653 DOI: 10.1046/j.1432-1327.1998.2550647.x.

(17) Van Lis, R.; Nitschke, W.; Duval, S.; Schoepp-Cothenet, B. Arsenics as bioenergetic substrates. Biochim. Biophys. Acta - Bioenerg. 2013, 1827 (2), 176-188 DOI: 10.1016/j.bbabio.2012.08.007.

(18) Mukhopadhyay, R.; Rosen, B. P. Arsenate reductases in prokaryotes and eukaryotes. Environ. Health Perspect. 2002, 110, 745-748 DOI: 10.1289/ehp.02110s5745.

(19) Wysocki, R.; Goffeau, A. Isolation of three contiguous genes, ACR1, ACR2 and ACR3, involved in resistance to arsenic compounds in the yeast Saccharomyces cerevisiae. Yeast 1997, 13, 819-828 DOI: 10.1002/(SICI)1097-0061(199707)13.

(20) David J. Thomas; Barry P. Rosen. Arsenic Methyltransferase. In Encyclopedia of Metalloproteins; Uversky, V. N., Kretsinger, R. H., Permyakov, Ei. E. a., Eds.; Science+Business Media: New York, 2013; pp 138-143 DOI: 10.1007/978-1-4614-1533-6.

(21) Chrysostomou, C.; Quandt, E. M.; Marshall, N. M.; Stone, E.; Georgiou, G. An alternate pathway of arsenate resistance in E. coli mediated by the glutathione S-transferase GstB. ACS Chem. Biol. 2015, 10 (3), 875-882 DOI: 10.1021/cb500755j.

(22) Chauhan, N. S.; Ranjan, R.; Purohit, H. J.; Kalia, V. C.; Sharma, R. Identifcation of genes conferring arsenic resistance to Escherichia coli from an effluent treatment plant sludge metagenomic library. FEMS Microbiol Ecol 2009, 67, 130-139 DOI:

10.1111/j.1574-6941.2008.00613.x.

(23) Qin, J.; Rosen, B. P.; Zhang, Y.; Wang, G.; Franke, S.; Rensing, C. Arsenic detoxification and evolution of trimethylarsine gas by a microbial arsenite S-adenosylmethionine methyltransferase. Proc. Natl. Acad. Sci. 2006, 103 (7), 2075-2080 DOI:

10.1073/pnas.0506836103. 
(24) Yoshinaga, M.; Rosen, B. P. A C · As lyase for degradation of environmental organoarsenical herbicides and animal husbandry growth promoters. Proc. Natl Acad. Sci. 2014, 111 (21), 7701-7706 DOI: 10.1073/pnas.1403057111.

(25) Louis S. Tisa; Rose, B. P. Molecular characterization of an anion pump-The ArsB protein is the membrane anchor for the ArsA protein. J. Biol. Chem. 1990, 265, 190-194.

(26) Lin, Y.; Walmsley, A. R.; Rosen, B. P. An arsenic metallochaperone for an arsenic detoxification pump. Proc. Natl Acad. Sci. 2006, 103 (42), 15617-15622 DOI: 10.1073/pnas.0603974103.

(27) Yang, H.; Cheng, J.; Finan, T. M.; Rosen, B. P. Novel pathway for arsenic detoxification in the legume symbiont Sinorhizobium meliloti. J. Bacteriol. 2005, 187 (20), 6991-6997 DOI: 10.1128/JB.187.20.6991.

(28) Ghosh, M.; Shen, J.; Rosen, B. P. Pathways of As (III) detoxification in Saccharomyces cerevisiae. Proc. Natl Acad. Sci. 1999, 96, 5001-5006 DOI: 10.1073/pnas.96.9.5001.

(29) Chen, J.; Yoshinaga, M.; Garbinski, L. D.; Rosen, B. P. Synergistic interaction of glyceraldehydes-3-phosphate dehydrogenase and ArsJ, a novel organoarsenical efflux permease, confers arsenate resistance. Mol. Microbiol. 2016, 100 (6), 945-953 DOI: 10.1111/mmi.13371.

(30) Chen, J.; Madegowda, M.; Bhattacharjee, H.; Rosen, B. P. ArsP: A methylarsenite efflux permease. Mol. Microbiol. 2015, 98 (4), 625-635 DOI: 10.1111/mmi.13145.

(31) Grondin, K.; Haimeur, A.; Mukhopadhyay, R.; Rosen, B. P.; Ouellette, M. Co-amplification of the gamma-glutamylcysteine synthetase gene gsh1 and of the ABC transporter gene pgpA in arsenite-resistant Leishmania tarentolae. EMBO J. 1997, 16 (11), 3057-3065 DOI: 10.1093/emboj/16.11.3057.

(32) Wang, L.; Chen, S.; Xiao, X.; Huang, X.; You, D.; Zhou, X.; Deng, Z. arsRBOCT arsenic resistance system encoded by linear plasmid pHZ227 in Streptomyces sp. strain FR-008. Appl Env. Microbiol 2006, 72 (5), 3738-3742 DOI: 10.1128/AEM.72.5.3738.

(33) Oremland, R. S.; Saltikov, C. W.; Wolfe-Simon, F.; Stolz, J. F. Arsenic in the Evolution of Earth and Extraterrestrial Ecosystems. Geomicrobiol. J. 2009, 26 (V), 522-536 DOI: $10.1080 / 01490450903102525$.

(34) McCann, S. H.; Boren, A.; Hernandez-maldonado, J.; Stoneburner, B.; Saltikov, C. W.; Stolz, J. F.; Oremland, R. S. Arsenite as an Electron Donor for Anoxygenic Photosynthesis: Description of Three Strains of Ectothiorhodospira from Mono Lake, California and Big Soda Lake, Nevada. Life 2016, 7 (1), 1-14 DOI: 10.3390/life7010001.

(35) Hernandez-maldonado, J.; Sanchez-sedillo, B.; Stoneburner, B.; Boren, A.; Miller, L.; Mccann, S.; Rosen, M.; Oremland, R. S.; Saltikov, C. W. The genetic basis of anoxygenic photosynthetic arsenite oxidation. Env. Microbiol 2017, 19, 130-141 DOI: $10.1111 / 1462-2920.13509$.

(36) Kulp, T. R.; Hoeft, S. E.; Asao, M.; Madigan, M. T.; Hollibaugh, J. T.; Fisher, J. C.; Stolz, J. F.; Culbertson, C. W.; Miller, L. G.; Oremland, R. S. Arsenic(III) fuels anoxygenic photosynthesis in hot spring biofilms from Mono Lake, California. Science 2008, 321 (5891), 967-970 DOI: 
(37) Hoeft, S. E.; Kulp, T. R.; Han, S.; Lanoil, B.; Oremland, R. S. Coupled arsenotrophy in a hot spring photosynthetic biofilm at mono lake, California. Appl. Environ. Microbiol. 2010, 76 (14), 4633-4639 DOI: 10.1128/AEM.00545-10.

(38) Oremland, R. S.; Hoeft, S. E.; Santini, J. M.; Bano, N.; Hollibaugh, R. a; Hollibaugh, J. T. Anaerobic Oxidation of Arsenite in Mono Lake Water and by a Facultative, Arsenite-Oxidizing Chemoautotroph, Strain MLHE-1. Appl Env. Microbiol 2002, 68 (10), 4795-4802 DOI: 10.1128/AEM.68.10.4795.

(39) Kulp, T. R. Arsenic and primordial life. Nat. Geosci. 2014, 7 (11), 785-786 DOI: $10.1038 /$ ngeo 2275 .

(40) Stolz, J. F.; Basu, P.; Oremland, R. S. Microbial Arsenic Metabolism: New Twists on an Old Poison. Microbe 2010, 5 (2), 53-59 DOI: 10.1128/microbe.5.53.1.

(41) Branco, R.; Francisco, R.; Chung, A. P.; Morais, P. V. Identification of an aox system that 692

(42) Zargar, K.; Hoeft, S.; Oremland, R.; Saltikov, C. W. Identification of a novel arsenite oxidase 695

(43) Hery, M.; Gault, A. G.; Rowland, H. A. L.; Lear, G.; Polya, D. A.; Lloyd, J. R. Molecular and 698

(44) Pederick, R. L.; Gault, A. G.; Charnock, J. M.; Polya, D. A.; Lloyd, J. R. Probing the biogeochemistry of arsenic: Response of two contrasting aquifer sediments from Cambodia to stimulation by arsenate and ferric iron. J. Environ. Sci. Heal. Part A 2007, 42, 1763-1774 DOI: $10.1080 / 10934520701564269$.

(45) Yan, Y.; Ding, K.; Yu, X.; Ye, J.; Xue, X. Ability of Periplasmic Phosphate Binding Proteins from Synechocystis sp . PCC 6803 to Discriminate Phosphate Against Arsenate. Water. Air. Soil Pollut. 2017, 228, 148 DOI: 10.1007/s11270-017-3334-4. arsenate reductase activity of the catalytic domain of the human Cdc25B and Cdc25C phosphatases. Biochemistry 2010, 49 (4), 802-809 DOI: 10.1021/bi9019127. orientation of the hydrophobic moments of multi-domain proteins. Int. J. Bioinform. Res. Appl. 2006, 2 (2), 161-176 DOI: 10.1016/j.molbiopara.2006.03.009. Wang, P.; Sun, G.; Jia, Y.; Meharg, A. A.; Zhu, Y. A review on completing arsenic biogeochemical cycle: Microbial volatilization of arsines in environment. J. Environ. Sci. 2014, 26, 371-381 DOI: 10.1016/S1001-0742(13)60432-5.

Yin, X.-X.; Chen, J.; Qin, J.; Sun, G.-X.; Rosen, B. P.; Zhu, Y.-G. Biotransformation and volatilization of arsenic by three photosynthetic cyanobacteria. Plant Physiol. 2011, 156 (3), 
1631-1638 DOI: 10.1104/pp.111.178947.

(50) Yin, X. X.; Zhang, Y. Y.; Yang, J.; Zhu, Y. G. Rapid biotransformation of arsenic by a model protozoan Tetrahymena thermophila. Environ. Pollut. 2011, 159 (4), 837-840 DOI: 10.1016/j.envpol.2010.12.033.

(51) Ye, J.; Rensing, C.; Rosen, B. P.; Zhu, Y. G. Arsenic biomethylation by photosynthetic organisms. Trends Plant Sci. 2012, 17 (3), 155-162 DOI: 10.1016/j.tplants.2011.12.003.

(53) Stolz, J. F.; Perera, E.; Kilonzo, B.; Kail, B.; Crable, B.; Fisher, E.; Ranganathan, M.; Wormer,

(54) Lehr, C. R.; Polishchuk, E.; Radoja, U.; Cullen, W. R. Demethylation of methylarsenic species

(55) Yoshinaga, M.; Cai, Y.; Rosen, B. P. Demethylation of methylarsonic acid by a microbial

(56) Yan, Y.; Ye, J.; Xue, X.-M.; Zhu, Y.-G. Arsenic Demethylation by a C · As Lyase in

(59) Morita, M.; Shibata, Y. Isolation and identification of arseno-lipid from a brown alga, Undaria pinnatifida (Wakame). Chemosphere 1988, 17 (6), 1147-1152 DOI:

10.1016/0045-6535(88)90180-4.

(60) Garcii'a-Salgado1, S.; Raber, G.; Raml, R.; Magnes, C.; Francesconi, K. A. Arsenosugar phospholipids and arsenic hydrocarbons in two species of brown macroalgae. Environ. Chem. 2012, 9, 63-66 DOI: 10.1071/EN11164.

(61) Xue, X.-M.; Raber, G.; Foster, S.; Chen, S.-C.; Francesconi, K. A.; Zhu, Y.-G. Biosynthesis of arsenolipids by the cyanobacterium Synechocystis sp. PCC 6803. Environ. Chem. 2014, 11 (5), 506-513 DOI: 10.1071/EN14069.

Gunnlaugsdottir, H.; Francesconi, K. A. Arsenic-containing long-chain fatty acids in cod-liver oil: A result of biosynthetic infidelity? Angew. Chemie - Int. Ed. 2008, 47 (14), 2665-2667 
DOI: 10.1002/anie.200705405.

(63) Raab, A.; Newcombe, C.; Pitton, D.; Ebel, R.; Feldmann, J. Comprehensive analysis of lipophilic arsenic species in a brown alga (Saccharina latissima). Anal. Chem. 2013, 85 (5), 2817-2824 DOI: 10.1021/ac303340t.

(64) Taleshi, M. S.; Raber, G.; Edmonds, J. S.; Jensen, K. B.; Francesconi, K. A. Arsenolipids in oil from blue whiting Micromesistius poutassou--evidence for arsenic-containing esters. Sci. Rep. 2014, 4, 7492 DOI: 10.1038/srep07492.

(65) Taleshi, M. S.; Edmonds, J. S.; Goessler, W.; Ruiz-Chancho, M. J.; Raber, G.; Jensen, K. B.; Francesconi, K. A. Arsenic-containing lipids are natural constituents of sashimi tuna. Environ. Sci. Technol. 2010, 44 (4), 1478-1483 DOI: 10.1021/es9030358.

(66) Taleshi, M. S.; Jensen, K. B.; Raber, G.; Edmonds, J. S.; Gunnlaugsdottir, H.; Francesconi, K. A. Arsenic-containing hydrocarbons: natural compounds in oil from the fish capelin, Mallotus villosus. Chem. Commun. 2008, 39 (39), 4706-4707 DOI: 10.1039/b808049f.

(67) Amayo, K. O.; Raab, A.; Krupp, E. M.; Gunnlaugsdottir, H.; Feldmann, J. Novel identification of arsenolipids using chemical derivatizations in conjunction with RP-HPLC-ICPMS/ESMS. Anal. Chem. 2013, 85 (19), 9321-9327 DOI: 10.1021/ac4020935.

(68) Viczek, S. A.; Jensen, K. B.; Francesconi, K. A. Arsenic-containing Phosphatidylcholines: a New Group of Arsenolipids Discovered in Herring Caviar. Angew. Chemie Int. Ed. 2016, 55, 5259-5262 DOI: 10.1002/anie.201512031.

(69) Van Mooy, B. a S.; Fredricks, H. F.; Pedler, B. E.; Dyhrman, S. T.; Karl, D. M.; Koblízek, M.; Lomas, M. W.; Mincer, T. J.; Moore, L. R.; Moutin, T.; et al. Phytoplankton in the ocean use non-phosphorus lipids in response to phosphorus scarcity. Nature 2009, 458, 69-72 DOI: 10.1038/nature07659.

(70) Petursdottir, A. H.; Fletcher, K.; Gunnlaugsdottir, H.; Krupp, E.; Kupper, F. C.; Feldmann, J. Environmental effects on arsenosugars and arsenolipids in Ectocarpus (Phaeophyta). Environ. Chem. 2016, 13 (1), 21-33 DOI: 10.1071/EN14229.

(71) Meyer, S.; Matissek, M.; Müller, S. M.; Taleshi, M. S.; Ebert, F.; Francesconi, K. A.; Schwerdtle, T. In vitro toxicological characterisation of three arsenic-containing hydrocarbons. Metallomics 2014, 6, 1023-1033 DOI: 10.1039/c4mt00061g.

(72) Schmeisser, E.; Goessler, W.; Francesconi, K. A. Human metabolism of arsenolipids present in cod liver. Anal. Bioanal. Chem. 2006, 385 (2), 367-376 DOI: 10.1007/s00216-006-0401-X.

(73) Taylor, V.; Goodale, B.; Raab, A.; Schwerdtle, T.; Reimer, K.; Conklin, S.; Karagas, M. R.; Francesconi, K. A. Human exposure to organic arsenic species from seafood. Sci. Total Environ. 2017, 580, 266-282 DOI: 10.1016/j.scitotenv.2016.12.113.

(74) Planer-friedrich, B.; Suess, E.; Scheinost, A. C.; Wallschla, D. Arsenic speciation in sulfidic waters: Reconciling contradictory spectroscopic and chromatographic evidence. Anal. Chem. 2010, 82 (24), 10228-10235 DOI: 10.1021/ac1024717.

(75) Fisher, J. C.; Wallschlager, D.; Planer-Friendrich B., H. J. T. A new role for sulfur in arsenic cycling. Environ. Sci. Technol. 2008, 42 (1), 81-85 DOI: 10.1021/es0713936.

(76) Planer-Friedrich, B.; London, J.; Mccleskey, R. B.; Nordstrom, D. K.; Wallschlager, D. 
Thioarsenates in geothermal waters of yellowstone National Park: Determination, preservation, and geochemical importance. Environ. Sci. Technol. 2007, 41 (15), 5245-5251 DOI: $10.1021 / \mathrm{es} 070273 \mathrm{v}$.

802

(77) Taylor, P.; Planer-friedrich, B.; Fisher, J. C.; Hollibaugh, J. T.; Süß, E.; Planer-friedrich, B.; Fisher, J. C.; Hollibaugh, J. T.; Elke, S.; Wallschl, D. Oxidative Transformation of Trithioarsenate Along Alkaline Geothermal Drainages - Abiotic versus Microbially Mediated Processes. Geomicrobiol J 2009, 26, 339-350 DOI: 10.1080/01490450902755364.

(78) Planer-friedrich, B.; Hartig, C.; Lohmayer, R.; Suess, E.; Mccann, S. H.; Oremland, R. Anaerobic chemolithotrophic growth of the haloalkaliphilic bacterium strain MLMS-1 by disproportionation of monothioarsenate. Env. Sci Technol 2015, 49, 6554-6563 DOI: 10.1021/acs.est.5b01165.

(79) Härtig, C.; Planer-friedrich, B. Thioarsenate transformation by filamentous microbial mats thriving in an alkaline, sulfidic hot Spring. Environ. Sci. Technol. 2012, 46 (8), 4348-4356 DOI: $10.1021 / \mathrm{es} 204277 \mathrm{j}$.

(80) Hartig, C.; Lohmayer, R.; Kolb, S.; Horn, M. A.; Inskeep, W. P.; Planer-friedrich, B. Chemolithotrophic growth of the aerobic hyperthermophilic bacterium Thermocrinis ruber OC 14/7/2 on monothioarsenate and arsenite. FEMS Microbiol Ecol 2014, 90, 747-760 DOI: 10.1111/1574-6941.12431.

(81) Edwardson, C. F.; Planer-friedrich, B.; Hollibaugh, J. T. Transformation of monothioarsenate by haloalkaliphilic, anoxygenic photosynthetic purple sulfur bacteria. FEMS Microbiol Ecol 2014, 90, 858-868 DOI: 10.1111/1574-6941.12440.

(82) Tamaki, S.; Frankenberger, W. T. J. Environmental biochemistry of arsenic. In Reviews of environmental contamination and toxicology; Ware, G. W., Ed.; Springer New York: United States, 1992; Vol. 124, pp 79-110 DOI: 10.1007/978-1-4612-2864-6_4

(83) Ali, W.; Isayenkov, S. V.; Zhao, F. J.; Maathuis, F. J. M. Arsenite transport in plants. Cell. Mol. Life Sci. 2009, 66 (14), 2329-2339 DOI: 10.1007/s00018-009-0021-7.

(84) Broer, S.; Ji, G.; Broer, A.; Silver, S. Arsenic efflux governed by the arsenic resistance determinant of Staphylococcus aureus plasmid pI258. J. Bacteriol. 1993, 175 (11), 3480-3485 DOI: $10.1128 / \mathrm{jb} .175 .11 .3480-3485.1993$.

(85) Chen, X.-P.; Zhu, Y.-G.; Hong, M.-N.; Kappler, A.; Xu, Y.-X. Effects of different forms of nitrogen fertilizers on arsenic uptake by rice plants. Environ. Toxicol. Chem. 2008, 27 (4), 881-887 DOI: 10.1897/07-368.1.

(86) Handley, K. M.; Mcbeth, J. M.; Charnock, J. M.; Vaughan, D. J.; Wincott, P. L.; Polya, D. A.; Lloyd, J. R. Effect of iron redox transformations on arsenic solid-phase associations in an arsenic-rich, ferruginous hydrothermal sediment. Geochim. Cosmochim. Acta 2013, 102, 124-142 DOI: 10.1016/j.gca.2012.10.024.

(87) Carlson, H. K.; Clark, I. C.; Blazewicz, S. J.; Iavarone, A. T.; Coates, J. D. Fe(II) oxidation is an innate capability of nitrate-reducing bacteria that involves abiotic and biotic reactions. $J$. Bacteriol. 2013, 195 (14), 3260-3268 DOI: 10.1128/JB.00058-13.

(88) Bertin, P. N.; Heinrich-Salmeron, A.; Pelletier, E.; Goulhen-Chollet, F.; Arsène-Ploetze, F.; 

main microorganisms inside an arsenic-rich ecosystem revealed by meta- and proteo-genomics. ISME J. 2011, 5 (11), 1735-1747 DOI: 10.1038/ismej.2011.51.

(89) Melton, E. D.; Swanner, E. D.; Behrens, S.; Schmidt, C.; Kappler, A. The interplay of microbially mediated and abiotic reactions in the biogeochemical Fe cycle. Nat. Rev. Microbiol. 2014, 12 (12), 797-809 DOI: 10.1038/nrmicro3347.

(90) Masscheleyn, P. H.; Delaune, R. D.; Patrick, Jr., W. H. Effect of redox potential and pH on 1414-1419 DOI: 10.1021/es00020a008. arsenic speciation and solubility in a contaminated soil. Environ. Sci. Technol. 1991, 25 (8),

(93) Borch, T.; Kretzschmar, R.; Kappler, A.; Van Cappellen, P.; Ginder-Vogel, M.; Voegelin, A.;

(95) Liu, W. J.; Zhu, Y. G.; Smith, F. A.; Smith, S. E. Do iron plaque and genotypes affect arsenate 862

(96) Liu, W. J.; Zhu, Y. G.; Hu, Y.; Williams, P. N.; Gault, A. G.; Meharg, A. A.; Charnock, J. M.;

(97) Chen, Z.; Zhu, Y. G.; Liu, W. J.; Meharg, A. A. Direct evidence showing the effect of root Smith, F. A. Arsenic sequestration in iron plaque, its accumulation and speciation in mature rice plants (Oryza sativa L.). Environ. Sci. Technol. 2006, 40 (18), 5730-5736 DOI: $10.1021 / \mathrm{es} 060800 \mathrm{v}$. surface iron plaque on arsenite and aresnate uptake in rice (Oryza sativa) roots. New Phytol. 2005, 165 (1), 91-97 DOI: 10.1111/j.1469-8137.2004.01241.x. Reyes, C.; Lloyd, J. R.; Saltikov, C. W. Geomicrobiology of Iron and Arsenic in Anoxic Sediments. In Arsenic Contamination of Groundwater; Ahuja, S., Ed.; John Wiley \& Sons, Inc.: Hoboken, NJ, USA, 2008; pp 123-146 DOI: 10.1002/9780470371046.ch6 Lloyd, J. R.; Oremland, R. Microbial Transformations of Arsenic in the Environment: From Soda Lakes to Aquifers. Elements 2006, 2, 85-90 DOI: 10.2113/gselements.2.2.85. J. R. Role of metal-reducing bacteria in arsenic release from Bengal delta sediments. Nature 2004, 430 (6995), 68-71 DOI: 10.1038/nature02638. 
(101) Cummings, D. E.; Caccavo, F.; Fendorf, S.; Rosenzweig, R. F. Arsenic mobilization by the dissimilatory Fe(III)-reducing bacterium Shewanella alga BrY. Environ. Sci. Technol. 1999, 33 (5), 723-729 DOI: 10.1021/es980541c.

(102) Wang, X.-J.; Chen, X.-P.; Kappler, A.; Sun, G.-X.; Zhu, Y.-G. Arsenic binding to iron (II) minerals produced by an iron (III)-reducing aeromonas strain isolated from paddy soil. Environ. Toxicol. Chem. 2009, 28 (11), 2255-2262 DOI: 10.1897/09-085.1.

(103) Muehe, E. M.; Scheer, L.; Daus, B.; Kappler, A. Fate of arsenic during microbial reduction of biogenic versus abiogenic As-Fe(III)-mineral coprecipitates. Environ. Sci. Technol. 2013, 47 (15), 8297-8307 DOI: 10.1021/es400801z.

(104) Muehe, E. M.; Morin, G.; Scheer, L.; Le Pape, P.; Esteve, I.; Daus, B.; Kappler, A. Arsenic(V) Incorporation in Vivianite during Microbial Reduction of Arsenic(V)-Bearing Biogenic Fe(III) (Oxyhydr)oxides. Environ. Sci. Technol. 2016, 50 (5), 2281-2291 DOI: 10.1021/acs.est.5b04625.

(105) Islam, F. S.; Pederick, R. L.; Gault, A. G.; Adams, L. K.; Polya, D. A.; Charnock, J. M.; Lloyd, J. R. Interactions between the Fe(III) -Reducing Bacterium Geobacter sulfurreducens and Arsenate, and Capture of the Metalloid by Biogenic Fe(II). Appl Env. Microbiolli 2005, 71 (12), 8642-8648 DOI: 10.1128/AEM.71.12.8642.

(106) Islam, F. S.; Boothman, C.; Gault, A. G.; Polya, D. A.; Lloyd, J. R. Potential role of the Fe(III)-reducing bacteria Geobacter and Geothrix in controlling arsenic solubility in Bengal delta sediments. Mineral. Mag. 2005, 69 (5), 865-875 DOI: 10.1180/0026461056950294.

(107) Wang, X.; Chen, X.; Yang, J.; Wang, Z.; Sun, G. Effect of microbial mediated iron plaque reduction on arsenic mobility in paddy soil. J. Environ. Sci. 2009, 21 (11), 1562-1568 DOI: 10.1016/S1001-0742(08)62456-0.

(108) Campbell, K. M.; Malasarn, D. Simultaneous Microbial Reduction of Iron(III) and Arsenic(V) in Suspensions of Hydrous Ferric Oxide. Env. Sci Technol 2006, 40 (19), 5950-5955 DOI: $10.1021 / \mathrm{es} 0600476$.

(109) Kocar, B. D.; Herbel, M. J.; Tufano, K. J.; Fendorf, S. Contrasting effects of dissimilatory iron(III) and arsenic(V) reduction on arsenic retention and transport. Environ. Sci. Technol. 2006, 40 (21), 6715-6721 DOI: 10.1021/es061540k.

(110) Oremland, R. S.; Stolz, J. F. Arsenic, microbes and contaminated aquifers. Trends Microbiol. 2005, 13 (2), 45-49 DOI: 10.1155/2011/863623.

(111) Zobrist, J.; Dowdle, P. R.; Davis, J. A.; Oremland, R. S. Mobilization of arsenite by dissimilatory reduction of adsorbed arsenate. Environ. Sci. Technol. 2000, 34 (22), 4747-4753 DOI: $10.1021 / \mathrm{es} 001068 \mathrm{~h}$.

(112) Hohmann, C.; Winkler, E.; Morin, G.; Kappler, A. Anaerobic Fe(II)-oxidizing bacteria show as resistance and immobilize as during Fe(III) mineral precipitation. Environ. Sci. Technol. 2010, 44 (1), 94-101 DOI: 10.1021/es900708s.

(113) Hohmann, C.; Morin, G.; Ona-Nguema, G.; Guigner, J. M.; Brown, G. E.; Kappler, A. Molecular-level modes of As binding to Fe(III) (oxyhydr)oxides precipitated by the anaerobic nitrate-reducing Fe(II)-oxidizing Acidovorax sp. strain BoFeN1. Geochim. Cosmochim. Acta 
2011, 75 (17), 4699-4712 DOI: 10.1016/j.gca.2011.02.044.

(114) Omoregie, E. O.; Couture, R.; Cappellen, P. Van; Corkhill, C. L.; Charnock, J. M.; Polya, D. A.; Vaughan, D.; Vanbroekhoven, K.; Lloyd, R. Arsenic Bioremediation by Biogenic Iron Oxides and Sulfides. Appl Env. Microbiol 2013, 79 (14), 4325-4335 DOI: 10.1128/AEM.00683-13.

(115) Nitzsche, K. S.; Weigold, P.; Lösekann-Behrens, T.; Kappler, A.; Behrens, S. Microbial community composition of a household sand filter used for arsenic, iron, and manganese removal from groundwater in Vietnam. Chemosphere 2015, 138, 47-59 DOI: 10.1016/j.chemosphere.2015.05.032.

(116) Kleinert, S.; Muehe, E. M.; Posth, N. R.; Dippon, U.; Daus, B.; Kappler, A. Biogenic Fe(III) minerals lower the efficiency of iron-mineral-based commercial filter systems for arsenic removal. Environ. Sci. Technol. 2011, 45 (17), 7533-7541 DOI: 10.1021/es201522n.

(117) Okibe, N.; Koga, M.; Morishita, S.; Tanaka, M.; Heguri, S.; Asano, S.; Sasaki, K.; Hirajima, T. Microbial formation of crystalline scorodite for treatment of As(III) -bearing copper refinery process solution using Acidianus brierleyi. Hydrometallurgy 2014, 143, 34-41 DOI: 10.1016/j.hydromet.2014.01.008.

(118) Mandal, B. K.; Suzuki, K. T. Arsenic round the world : a review. Talanta 2002, 58, 201-235 DOI: $10.1016 / \mathrm{S} 0039-9140(02) 00268-0$.

(119) Corkhill, C. L.; Wincott, P. L.; Lloyd, J. R.; Vaughan, D. J. The oxidative dissolution of arsenopyrite (FeAsS) and enargite (Cu3AsS4) by Leptospirillum ferrooxidans. Geochim. Cosmochim. Acta 2008, 72 (23), 5616-5633 DOI: 10.1016/j.gca.2008.09.008.

(120) O’Day, P. a; Vlassopoulos, D.; Root, R.; Rivera, N. The influence of sulfur and iron on dissolved arsenic concentrations in the shallow subsurface under changing redox conditions. Proc. Natl. Acad. Sci. U. S. A. 2004, 101 (38), 13703-13708 DOI: 10.1073/pnas.0402775101.

(121) Kim, M.; Nriagu, J.; Haack, S. Arsenic species and chemistry in groundwater of southeast Michigan. Environ. Pollut. 2002, 120, 379-390 DOI: 10.1016/S0269-7491(02)00114-8.

(122) Rochette, E. A.; Bostick, B. C.; Li, G.; Fendorf, S. Kinetics of arsenate reduction by dissolved sulfide. Environ. Sci. Technol. 2000, 34 (22), 4714-4720 DOI: 10.1021/es000963y.

(123) Kuhn, A.; Sigg, L.; Jul, N. Arsenic Cycling in Eutrophic Lake Greifen, Switzerland: Influence of Seasonal Redox Processes. Limnol. Ocean. 1993, 38 (5), 1052-1059 DOI: 10.4319/10.1993.38.5.1052.

(124) Newman, D. K.; Beveridge, T. J. Precipitation of Arsenic Trisulfide by Desulfotomaculum auripigmentum. Appl. Environ. Microbiol. 1997, 63 (5), 2022-2028.

(125) Rittle, K. A.; Drever, J. I.; Colberg, P. J. S. Precipitation of Arsenic during Bacterial Sulfate Reduction. Geomicrobiol. J. 1995, 13 (1), 1-11 DOI: 10.1080/01490459509378000.

(126) Hoeft, S. E.; Kulp, T. R.; Stolz, J. F.; Hollibaugh, J. T.; Oremland, R. S. Dissimilatory Arsenate Reduction with Sulfide as Electron Donor: Experiments with Mono Lake Water and Isolation of Strain MLMS-1, a Chemoautotrophic Arsenate Respirer. Appl. Environ. Microbiol. 2004, 70 (5), 2741-2747 DOI: 10.1128/AEM.70.5.2741.

(127) Hollibaugh, J. T.; Budinoff, C.; Hollibaugh, R. A.; Ransom, B.; Bano, N. Sulfide Oxidation 

Microbiol 2006, 72 (3), 2043-2049 DOI: 10.1128/AEM.72.3.2043.

(128) Hoeft, S. E.; Blum, J. S.; Stolz, J. F.; Tabita, F. R.; Witte, B.; King, G. M.; Santini, J. M.; Oremland, R. S. Alkalilimnicola ehrlichii sp. nov., a novel, arsenite-oxidizing haloalkaliphilic gammaproteobacterium capable of chemoautotrophic or heterotrophic growth with nitrate or oxygen as the electron acceptor. Int. J. Syst. Evol. Microbiol. 2007, 57 (3), 504-512 DOI: 10.1099/ijs.0.64576-0.

(129) Rhine, E. D.; Phelps, C. D.; Young, L. Y. Anaerobic arsenite oxidation by novel denitrifying isolates. Environ. Microbiol. 2006, 8 (5), 899-908 DOI: 10.1111/j.1462-2920.2005.00977.x.

(130) Sun, W.; Sierra, R.; Fernandez, N.; Sanz, J. L.; Amils, R.; Legatzki, A.; Maier, R. M.; Amils, 969

(136) Sharma, P.; Rolle, M.; Kocar, B. D.; Fendorf, S.; Kapppler, A. Influence of Natural Organic

(137) Sharma, P.; Kappler, A. Desorption of arsenic from clay and humic acid-coated clay by 990

(138) Bauer, M.; Blodau, C. Arsenic distribution in the dissolved, colloidal and particulate size 993 fraction of experimental solutions rich in dissolved organic matter and ferric iron. Geochim. Cosmochim. Acta 2009, 73 (3), 529-542 DOI: 10.1016/j.gca.2008.10.030.

(139) Thomasarrigo, L. K.; Mikutta, C.; Byrne, J.; Barmettler, K.; Kappler, A.; Kretzschmar, R. Iron and Arsenic Speciation and Distribution in Organic Flocs from Streambeds of an Arsenic-Enriched Peatland. Environ. Sci. Technol. 2014, 48, 13218-13228 DOI: $10.1021 /$ es503550g. 
(140) Macalady, D. L.; Ranville, J. F. The chemistry and geochemistry of natural organic matter (NOM). In Perspectives in environmental chemistry; Macalady, D. L., Ed.; Oxford University Press: New York, 1988; pp 94-137.

(141) Buschmann, J.; Kappeler, A.; Lindauer, U.; Kistler, D.; Berg, M.; Sigg, L. Arsenite and arsenate binding to dissolved humic acids: Influence of $\mathrm{pH}$, type of humic acid, and aluminum. Environ. Sci. Technol. 2006, 40 (19), 6015-6020 DOI: 10.1021/es061057+.

(142) Sharma, P.; Ofner, J.; Kappler, A. Formation of binary and ternary colloids and dissolved complexes of organic matter, Fe and As. Environ. Sci. Technol. 2010, 44 (12), 4479-4485 DOI: $10.1021 /$ es $100066 \mathrm{~s}$.

(143) Langner, P.; Mikutta, C.; Kretzschmar, R. Arsenic sequestration by organic sulphur in peat. Nat. Geosci. 2011, 5 (1), 66-73 DOI: 10.1038/ngeo1329.

(144) Rowland, H. A. L.; Polya, D. A.; Lloyd, J. R.; Pancost, R. D. Characterisation of organic matter in a shallow, reducing, arsenic-rich aquifer, West Bengal. Org. Geochem. 2006, 37, 1101-1114 DOI: $10.1016 /$ j.orggeochem.2006.04.011.

(145) Rowland, H. A. L.; Pederick, R. L.; Polya, D. A.; Pancost, R. D.; Dongen, B. E. Van; Gault, A. G.; Vaughan, D. J.; Bryant, C.; Anderson, B.; Lloyd, J. R. The control of organic matter on microbially mediated iron reduction and arsenic release in shallow alluvial aquifers, Cambodia. Geobiology 2007, 5, 281-292 DOI: 10.1111/j.1472-4669.2007.00100.x.

(146) Rowland, H. A. L.; Boothman, C.; Pancost, R.; Gault, A. G.; Polya, D. A.; Lloyd, J. R. The Role of Indigenous Microorganisms in the Biodegradation of Naturally Occurring Petroleum, the Reduction of Iron, and the Mobilization of Arsenite from West Bengal. J. Environ. Qual. 2009, 38, 1598-1607 DOI: 10.2134/jeq2008.0223.

(147) Bauer, M.; Blodau, C. Mobilization of arsenic by dissolved organic matter from iron oxides, soils and sediments. Sci. Total Environ. 2006, 354 (2-3), 179-190 DOI: 10.1016/j.scitotenv.2005.01.027.

(148) Huang, H.; Jia, Y.; Sun, G.-X.; Zhu, Y.-G. Arsenic speciation and volatilization from flooded paddy soils amended with different organic matters-supporting information. Environ. Sci. Technol. 2012, 46 (4), 2163-2168 DOI: 10.1021/es203635s.

(149) Jia, Y.; Huang, H.; Chen, Z.; Zhu, Y. G. Arsenic uptake by rice is influenced by microbe-mediated arsenic redox changes in the rhizosphere. Environ. Sci. Technol. 2014, 48 (2), 1001-1007 DOI: 10.1021/es403877s.

(150) Palmer, N. E.; Freudenthal, J. H.; Wandruszka, R. Von. Reduction of Arsenates by Humic Materials. Environ. Chem. 2006, 3, 131-136 DOI: 10.1071/EN05081.

(151) Palmer, N. E.; Wandruszka, R. Von. Humic acids as reducing agents: the involvement of quinoid moieties in arsenate reduction. Environ. Sci. Pollut. Res. 2010, 17, 1362-1370 DOI: 10.1007/s11356-010-0322-2.

(152) Redman, A. D.; Macalady, D.; Ahmann, D. Natural organic matter affects arsenic speciation and sorption onto hematite. Environ. Sci. Technol. 2002, 36 (13), 2889-2896 DOI: 10.1021/es0112801.

(153) Niggemyer, A.; Spring, S.; Stackebrandt, E. Isolation and Characterization of a Novel As (V) 
-Reducing Bacterium: Implications for Arsenic Mobilization and the Genus Desulfitobacterium. Appl. Environ. Microbiol. 2001, 67 (12), 5568-5580 DOI: 10.1128/AEM.67.12.5568.

(154) Stolz, J. F.; Oremland, R. S. Bacterial respiration of arsenic and selenium. FEMS Microbiol Rev 1999, 23, 615-627 DOI: 10.1111/j.1574-6976.1999.tb00416.x.

(155) Handley, K. M.; Hery, M.; Lloyd, J. R. Redox cycling of arsenic by the hydrothermal marine bacterium Marinobacter santoriniensis. Env. Microbiol 2009, 11 (6), 1601-1611 DOI: 10.1111/j.1462-2920.2009.01890.x.

(156) Lear, G.; Song, B.; Gault, A. G.; Polya, D. A.; Lloyd, J. R. Molecular analysis of arsenate-reducing bacteria within Cambodian sediments following amendment with acetate. Appl. Environ. Microbiol. 2007, 73 (4), 1041-1048 DOI: 10.1128/AEM.01654-06.

(157) Liu, A.; Garcia-dominguez, E.; Rhine, E. D.; Young, L. Y. A novel arsenate respiring isolate that can utilize aromatic substrates. FEMS Microbiol Ecol 2004, 48, 323-332 DOI: 10.1016/j.femsec.2004.02.008.

(158) Liu, W. J.; McGrath, S. P.; Zhao, F. J. Silicon has opposite effects on the accumulation of inorganic and methylated arsenic species in rice. Plant Soil 2014, 376 (1-2), 423-431 DOI: 10.1007/s11104-013-1991-7.

(159) Escudero, L. V; Casamayor, E. O.; Chong, G.; Pedro, C.; Demergasso, C. Distribution of Microbial Arsenic Reduction, Oxidation and Extrusion Genes along a Wide Range of Environmental Arsenic Concentrations. PLoS One 2013, 8 (10), e78890 DOI: 10.1371/journal.pone.0078890.

(160) Han, Y.; Fu, J.; Xiang, P.; Cao, Y.; Rathinasabapathi, B.; Chen, Y.; Ma, L. Q. Arsenic and phosphate rock impacted the abundance and diversity of bacterial arsenic oxidase and reductase genes in rhizosphere of As-hyperaccumulator Pteris vittata. J. Hazard. Mater. 2017, 321 , 146-153 DOI: 10.1016/j.jhazmat.2016.08.079.

(161) Wang, X.; Rathinasabapathi, B.; Oliveira, L. M. de; Guilherme, L. R. G.; Ma, L. Q. Bacteria-Mediated Arsenic Oxidation and Reduction in the Growth Media of Arsenic Hyperaccumulator Pteris vittata. Env. Sci Technol 2012, 46, 11259-11266 DOI: 10.1021/es300454b.

(162) Zhang, S. Y.; Zhao, F. J.; Sun, G. X.; Su, J. Q.; Yang, X. R.; Li, H.; Zhu, Y. G. Diversity and abundance of arsenic biotransformation genes in paddy soils from southern china. Environ. Sci. Technol. 2015, 49 (7), 4138-4146 DOI: 10.1021/acs.est.5b00028.

(163) Jia, Y.; Huang, H.; Sun, G. X.; Zhao, F. J.; Zhu, Y. G. Pathways and relative contributions to arsenic volatilization from rice plants and paddy soil. Environ. Sci. Technol. 2012, 46 (15), 8090-8096 DOI: 10.1021/es300499a.

(164) Xiao, K. Q.; Li, L. G.; Ma, L. P.; Zhang, S. Y.; Bao, P.; Zhang, T.; Zhu, Y. G. Metagenomic analysis revealed highly diverse microbial arsenic metabolism genes in paddy soils with low-arsenic contents. Environ. Pollut. 2016, 211, 1-8 DOI: 10.1016/j.envpol.2015.12.023.

(165) Lu, K.; Mahbub, R.; Cable, P. H.; Ru, H.; Parry, N. M. A.; Bodnar, W. M.; Wishnok, J. S.; Styblo, M.; Swenberg, J. A.; Fox, J. G.; et al. Gut Microbiome Phenotypes Driven by Host Genetics Affect Arsenic Metabolism. Chem. Res. Toxicol. 2014, 27, 172-174 DOI: 
(166) Cai, L.; Yu, K.; Yang, Y.; Chen, B. W.; Li, X. D.; Zhang, T. Metagenomic exploration reveals high levels of microbial arsenic metabolism genes in activated sludge and coastal sediments. Appl. Microbiol. Biotechnol. 2013, 97 (21), 9579-9588 DOI: 10.1007/s00253-012-4678-8.

(167) Rascovan, N.; Javier, M.; Martín P, V.; María, E. F. Metagenomic study of red biofilms from

(169) Sangwan, N.; Lambert, C.; Sharma, A.; Gupta, V.; Khurana, P.; Khurana, J. P.; Sockett, R. E.; Gilbert, J. A.; Lal, R. Arsenic rich Himalayan hot spring metagenomics reveal genetically novel predator - prey genotypes. Environ. Microbiol. Rep. 2015, 7, 812-823 DOI: 10.1111/1758-2229.12297.

(170) Aguiar-pulido, V.; Huang, W.; Suarez-ulloa, V.; Cickovski, T.; Mathee, K.; Narasimhan, G. Metagenomics, metatranscriptomics, and metabolomics approaches for microbiome analysis. Evol. Bioinforma. 2016, 12 (S1), 5-16 DOI: 10.4137/EBO.S36436.

(171) Kour, M. Isolation and Characterization of Metal Resistance Genes by using Metatranscriptomic Approach. Master Dissertation, Thapar University, Patiala, Punjab-147004, 2014.

(172) Carvalhais, L. C.; Dennis, P. G.; Tyson, G. W.; Schenk, P. M. Application of metatranscriptomics to soil environments. J. Microbiol. Methods 2012, 91 (2), 246-251 DOI: 10.1016/j.mimet.2012.08.011.

(173) Gilbert, J. A.; Field, D.; Huang, Y.; Edwards, R.; Li, W.; Gilna, P.; Joint, I. Detection of Large Numbers of Novel Sequences in the Metatranscriptomes of Complex Marine Microbial Communities. PLoS One 2008, 3 (8), e3042 DOI: 10.1371/journal.pone.0003042.

(174) Lafuente, A.; Patricia, P.; Molina-s, D.; Caviedes, M. A.; Rodr, I. D. Unraveling the effect of arsenic on the model Medicago - Ensifer interaction: a transcriptomic meta-analysis. ISME J. 2015, 205, 255-272 DOI: 10.1111/nph.13009.

(175) Zhang, Y.; Chen, S.; Hao, X.; Su, J. Q.; Xue, X.; Yan, Y.; Zhu, Y. G.; Ye, J. Transcriptomic analysis reveals adaptive responses of an enterobacteriaceae strain LSJC7 to arsenic exposure. Front. Microbiol. 2016, 7, 1-12 DOI: 10.3389/fmicb.2016.00636.

(176) Moran, M. A.; Satinsky, B.; Gifford, S. M.; Luo, H.; Rivers, A.; Chan, L.; Meng, J.; Durham, B. P.; Shen, C.; Varaljay, V. A.; et al. Sizing up metatranscriptomics. 2012, 7 (2), 237-243 DOI: 10.1038/ismej.2012.94.

(177) VerBerkmoes, N. C.; Denef, V. J.; Hettich, R. L.; Banfield, J. F. Functional analysis of natural microbial consortia using community proteomics. Nat Rev Microbiol 2009, 7 (3), 196-205 DOI: 10.1038/nrmicro2080.

(178) Fiehn, O. Metabolomics - The link between genotypes and phenotypes. Plant Mol. Biol. 2002, 
48 (1-2), 155-171 DOI: 10.1023/A:1013713905833.

(179) Schneider, T.; Riedel, K. Environmental proteomics: Analysis of structure and function of microbial communities. Proteomics 2010, 10 (4), 785-798 DOI: 10.1002/pmic.200900450.

(180) Lankadurai, B. P.; Nagato, E. G.; Simpson, M. J. Environmental metabolomics: an emerging approach to study organism responses to environmental stressors. Environ. Rev. 2013, 21, 180-205 DOI: 10.1139/er-2013-0011.

(181) Halter, D.; Cordi, A.; Gribaldo, S.; Gallien, S.; Goulhen-Chollet, F.; Heinrich-Salmeron, A.; Carapito, C.; Pagnout, C.; Montaut, D.; Seby, F.; et al. Taxonomic and functional prokaryote diversity in mildly arsenic-contaminated sediments. Res. Microbiol. 2011, 162 (9), 878-887 DOI: 10.1016/j.resmic.2011.06.001.

(182) Shi, X.; Wei, X.; Koo, I.; Schmidt, R. H.; Yin, X.; Kim, S. H.; Vaughn, A.; Mcclain, C. J.; Arteel, G. E.; Zhang, X.; et al. Metabolomic Analysis of the Effects of Chronic Arsenic Exposure in a Mouse Model of Diet-Induced Fatty Liver Disease. J. Proteome Res. 2014, 13, 547-554 DOI: 10.1021/pr400719u.

(183) Bastida, F.; Moreno, J. L.; Nicolás, C.; Hernández, T.; García, C. Soil metaproteomics: a review of an emerging environmental science. Significance, methodology and perspectives. Eur. J. Soil Sci. 2009, 60 (6), 845-859 DOI: 10.1111/j.1365-2389.2009.01184.x.

(184) Lu, K.; Abo, R. P.; Schlieper, K. A.; Michelle, E.; Levine, S.; Wishnok, J. S.; Swenberg, J. A.; Tannenbaum, S. R.; Fox, J. G. Arsenic Exposure Perturbs the Gut Microbiome and Its Metabolic Profile in Mice: An Integrated Metagenomics and Metabolomics Analysis. Environ. Health Perspect. 2014, 122, 284-291 DOI: 10.1289/ehp.1307429.

(185) Tripathi, R. D.; Tripathi, P.; Dwivedi, S.; Dubey, S.; Chatterjee, S.; Chakrabarty, D.; Trivedi, P. K. Arsenomics: Omics of arsenic metabolism in plants. Front. Physiol. 2012, 3, 1-14 DOI: 10.3389/fphys.2012.00275.

(186) Sacheti, P.; Bhonsle, H.; Patil, R.; Kulkarni, M. J.; Srikanth, R.; Gade, W. Arsenomics of Exiguobacterium sp. PS (NCIM 5463). RSC Adv. 2013, 3, 9705-9713 DOI: $10.1039 / \mathrm{c} 3 \mathrm{ra} 40897 \mathrm{c}$.

(187) Zhang, S.; Williams, P. N.; Luo, J.; Zhu, Y. Microbial mediated arsenic biotransformation in wetlands. Front. Environ. Sci. eng. 2017, 11 (1), 1-11 DOI: 10.1007/s11783-017-0893-y.

(188) Meharg, A. A.; Williams, P. N.; Adomako, E.; Lawgali, Y. Y.; Deacon, C.; Villada, A.; Cambell, R. C. J.; Sun, G.; Zhu, Y. G.; Feldmann, J.; et al. Geographical variation in total and inorganic arsenic content of polished (white) rice. Environ. Sci. Technol. 2009, 43 (5), 1612-1617 DOI: 10.1021/es802612a.

(189) Sun, G. X.; Williams, P. N.; Carey, A. M.; Zhu, Y. G.; Deacon, C.; Raab, A.; Feldmann, J.; Islam, R. M.; Meharg, A. A. Inorganic arsenic in rice bran and its products are an order of magnitude higher than in bulk grain. Environ. Sci. Technol. 2008, 42 (19), 7542-7546 DOI: $10.1021 / \mathrm{es} 801238 \mathrm{p}$.

(190) Sun, G. X.; Williams, P. N.; Zhu, Y. G.; Deacon, C.; Carey, A. M.; Raab, A.; Feldmann, J.; Meharg, A. A. Survey of arsenic and its speciation in rice products such as breakfast cereals, rice crackers and Japanese rice condiments. Environ. Int. 2009, 35 (3), 473-475 DOI: 
10.1016/j.envint.2008.07.020.

(191) Norton, G. J.; Pinson, S. R. M.; Alexander, J.; Mckay, S.; Hansen, H.; Duan, G.; Islam, M. R.; Islam, S.; Stroud, J. L.; Zhao, F.; et al. Variation in grain arsenic assessed in a diverse panel of rice (Oryza sativa) grown in multiple sites. New Phytol. 2011, 193, 650-664 DOI: 10.1111/j.1469-8137.2011.03983.x.

(192) Lomax, C.; Liu, W. J.; Wu, L.; Xue, K.; Xiong, J.; Zhou, J.; McGrath, S. P.; Meharg, A. A.; Miller, A. J.; Zhao, F. J. Methylated arsenic species in plants originate from soil microorganisms. New Phytol. 2012, 193 (3), 665-672 DOI: 10.1111/j.1469-8137.2011.03956.x.

(193) Oremland, R. S.; Dowdle, P. R.; Hoeft, S.; Sharp, J. O.; Schaefer, J. K.; Miller, L. G.; Blum, J. S.; Smith, R. L.; Bloom, N. S.; Wallschlager, D. Bacterial dissimilatory reduction of arsenate and sulfate in meromictic Mono Lake, California. Geochim. Cosmochim. Acta 2000, 64 (18), 3073-3084 DOI: 10.1016/S0016-7037(00)00422-1.

(194) Kulp, T. R.; Hoeft, S. E.; Miller, L. G.; Saltikov, C.; Murphy, J. N.; Han, S.; Lanoil, B.; Oremland, R. S. Dissimilatory Arsenate and Sulfate Reduction in Sediments of Two Hypersaline, Arsenic-Rich Soda Lakes: Mono and Searles Lakes, California. Appl. Environ. Microbiol. 2006, 72 (10), 6514-6526 DOI: 10.1128/AEM.01066-06.

(195) Reed, D. C.; Algar, C. K.; Huber, J. A.; Dick, G. J. Gene-centric approach to integrating environmental genomics and biogeochemical models. Proc. Natl Acad. Sci. 2014, 111 (5), 1879-1884 DOI: 10.1073/pnas.1313713111.

(196) Louca, S.; Hawley, A. K.; Katsev, S.; Torres-Beltran, M.; Bhatia, M. P.; Kheirandish, S.; Michiels, C. C.; Capelle, D.; Lavik, G.; Doebeli, M.; et al. Integrating biogeochemistry with multiomic sequence information in a model oxygen minimum zone. Proc. Natl. Acad. Sci. 2016, 113 (40), E5925-E5933 DOI: 10.1073/pnas.1602897113.

\section{Legends}

Figure 1. Proposed pathways for arsenic redox reactions and synthesis of novel organoarsenicals.

Figure 2. The model of effect of Fe, N, S and natural organic matter (NOM) on microbes involved in arsenic biogeochemical cycling highlights proteins associated with elemental metabolisms. Green ovals denote arsenic transporters, yellow ovals denote transmembrane enzymes. Red words are enzymes, blue words are related arsenic compounds. The full name of enzymes that were not mentioned in the text was provided in the follow, NarG, transmembrane nitrate reductase that drives the nitrate 
1195 reduction to nitrite; Nas, cytoplasmic-assimilatory nitrate reductase that drives the 1196 nitrate reduction to nitrite; NapA, periplasmic-dissimilatory nitrate reductase; Nir / Nrf 1197 (associated with NapA), nitrite reductase that drives the nitrite reduction to nitric 1198 oxide; NorB/C, nitric oxide reductase that drives the nitric oxide reduction to nitrous 1199 oxide; NosZ, nitrous oxide reductase that drives the nitrous oxide reduction to 1200 nitrogen; Nif, nitrogenase that catalyzes the nitrogen fixation to ammonia; Hs, 1201 hydrazine synthase that catalyzes the production of nitrogen from nitrous oxide and 1202 ammonia; cyt, cytochrome. 


\begin{tabular}{|c|c|c|c|c|}
\hline Gene & Protein & $\begin{array}{l}\text { Protein } \\
\text { abbreviation }\end{array}$ & function & Reference \\
\hline \multicolumn{5}{|l|}{ As(III) oxidation } \\
\hline aio $A$ and $a i o B$ & As(III) oxidase & AioAB & Oxidate As(III) & 9 \\
\hline $\operatorname{arxA}$ & As(III) oxidase & ArxAB & Oxidate As(III) & 10 \\
\hline $\operatorname{arxB} / \operatorname{arxB2}$ & [4Fe-4S] containing protein & $\begin{array}{l}\text { ArxB/ } \\
\text { ArxB2 }\end{array}$ & Unknown function & 11 \\
\hline aioX/arxX & As(III)-binding protein & AioX/ArxX & $\begin{array}{l}\text { Involved in } \mathrm{As}(\mathrm{III}) \text {-based signaling and } \\
\text { regulation of } \mathrm{As}(\mathrm{III}) \text { oxidation }\end{array}$ & 12,11 \\
\hline aioS/arxS & sensor histidine kinase & AioS /ArxS & $\begin{array}{l}\text { One part of two-component signal } \\
\text { transduction system }\end{array}$ & 9,11 \\
\hline aioR/arxR & transcriptional regulator & AioR/ArxR & Regulate the expression of aio/arx operon & 9,11 \\
\hline moeA & $\begin{array}{l}\text { molybdenum cofactor biosynthesis } \\
\text { protein }\end{array}$ & MoeA & $\begin{array}{l}\text { Synthesize the molybdenum cofactor of } \\
\text { AioAB oxidase }\end{array}$ & 9 \\
\hline $\operatorname{arx} C$ & $\begin{array}{l}\text { membrane anchoring and quinol } \\
\text { oxidoreductase subunit }\end{array}$ & ArxC & Involved in As(III) oxidation & 11 \\
\hline $\operatorname{arxD}$ & TorD-like molybdoenzyme chaperone & ArxD & Involved in As(III) oxidation & 11 \\
\hline arsH & organoarsenical oxidase & ArsH & $\begin{array}{l}\text { Oxidate trivalent methylated and aromatic } \\
\text { arsenicals, reduce chromium and iron }\end{array}$ & 13,14 \\
\hline \multicolumn{5}{|l|}{ As $(V)$ reduction } \\
\hline $\operatorname{arr} A$ and $\operatorname{arr} B$ & $\mathrm{As}(\mathrm{V})$ respiratory reductases & ArrAB & Reduce As(V) & 15,16 \\
\hline $\operatorname{arrC}$ & $\mathrm{As}(\mathrm{V})$ reductase membranous subunit & ArrC & Involved in $\mathrm{As}(\mathrm{V})$ reduction & 17 \\
\hline $\operatorname{arrD}$ & $\mathrm{As}(\mathrm{V})$ reductase chaperon & ArrD & Involved in $\mathrm{As}(\mathrm{V})$ reduction & 17 \\
\hline arrS & sensor histidine kinase & ArrS & Regulate the expression of arr operon & 17 \\
\hline $\operatorname{ars} C$ & $\mathrm{As}(\mathrm{V})$ reductase & $\mathrm{ArsC}$ & Reduce As(V) & 18 \\
\hline ACR2 & $\mathrm{As}(\mathrm{V})$ reductase & ACR2 & Reduce As(V) & 19 \\
\hline
\end{tabular}




\begin{tabular}{|c|c|c|c|c|}
\hline ACR1 & transcriptional regulatory protein & ACR1 & Regulate the expression of $A C R$ genes & 19 \\
\hline $\operatorname{arrR} / \operatorname{ars} R$ & arsenic-responsive repressor & ArrR /ArsR & Regulate the expression of arr/ars operon & 17,20 \\
\hline GstB & glutathione S-transferase B & GstB & $\begin{array}{l}\text { Reduce } \mathrm{As}(\mathrm{V}) \text { to } \mathrm{As}(\mathrm{III}) \text { with reduced } \\
\text { GSH }\end{array}$ & 21 \\
\hline $\operatorname{arsN}$ & acetyltransferase & ArsN & Putative $\mathrm{As}(\mathrm{V})$ reductase & 22 \\
\hline \multicolumn{5}{|c|}{ Arsenic methylation and demethylation } \\
\hline $\operatorname{arsM}$ & $\begin{array}{l}\text { As(III) S-adenosylmethionine (SAM) } \\
\text { methyltransferases }\end{array}$ & ArsM & Methylate arsenic & 23 \\
\hline arsI & A C $\cdot$ As lyase & ArsI & $\begin{array}{l}\text { Catalyze demethylation of trivalent } \\
\text { organoarsenicals }\end{array}$ & 24 \\
\hline \multicolumn{5}{|c|}{ Arsenic transport } \\
\hline $\operatorname{arsB}$ & As(III)-pump protein & ArsB & Extrude $\mathrm{As}(\mathrm{III})$ from the cell & 25 \\
\hline $\operatorname{ars} A$ & As(III)-pump ATPase & ArsA & $\begin{array}{l}\text { The catalytic subunit of an } \\
\text { oxyanion-translocating ATPase }\end{array}$ & 26 \\
\hline $\operatorname{ars} D$ & arsenical metallochaperone & ArsD & Transfer trivalent metalloids to ArsA & 26 \\
\hline apqS & aquaglyceroporin & AqpS & Extrude As(III) from the cell & 27 \\
\hline ACR3 & As(III) permease & ACR3 & Extrude $\mathrm{As}(\mathrm{III})$ from the cell & 19 \\
\hline$Y c f 1 p$ & $\begin{array}{l}\begin{array}{l}\text { yeast cadmium factor protein } \\
\text { cytosolic }\end{array} \\
\end{array}$ & Ycflp & $\begin{array}{l}\text { Sequester cytosolic As(III)/glutathione } \\
\text { complex into vacuoles }\end{array}$ & 28 \\
\hline arsJ & organoarsenical efflux permease & ArsJ & Extrude organoarsenicals from the cell & 29 \\
\hline $\operatorname{ars} P$ & $\begin{array}{l}\text { efflux system specific for trivalent } \\
\text { organoarsenicals }\end{array}$ & ArsP & $\begin{array}{l}\text { Extrude trivalent organoarsenicals from } \\
\text { the cell }\end{array}$ & 30 \\
\hline pgpA & P-glycoprotein-related protein & PgpA & $\begin{array}{l}\text { Recognize and transport thiol-metal } \\
\text { conjugates }\end{array}$ & 31 \\
\hline \multicolumn{5}{|c|}{ Unknown functions } \\
\hline $\operatorname{arsO}$ & $\begin{array}{l}\text { putative flavin-binding } \\
\text { monooxygenase }\end{array}$ & $\mathrm{ArsO}$ & Unknown function & 32 \\
\hline arsT & putative thioredoxin reductase & ArsT & Unknown function & 32 \\
\hline
\end{tabular}

